\title{
Fuel Performance Annual Report for 1979
}

Prepared by M. Tokar, U.S. Nuclear Regulatory Commission

W. J. Bailey, M. E. Cunningham

Pacific Northwest Laboratory

Operated by

Battelle Memorial Institute

Prepared for

U.S. Nuclear Regulatory

Commission 


\section{NOTICE}

This report was prepared as an account of work sponsored by an agency of the United States Government. Neither the United States Government nor any agency thereof, or any of their employees, makes any warranty, expressed or implied, or assumes any legal liability or responsibility for any third party's use, or the results of such use, of any information. apparatus product or process disclosed in this report, or represents that its use by such third party would not infringe privately owned rights.

\section{Available from}

GPO Sales Program

Division of Technical Information and Document Control

U. S. Nuclear Regulatory Commission

Washington, D. C. 20555

Printed copy price: $\$ 2.50$

and

National Technical Information Service

Springfield, Virginia 22161 
NUREG / CR-1818

PNL-3583

\section{Fuel Performance Annual Report for 1979}

Manuscript Completed: September 1980

Date Published: January 1981

Prepared by

M. Tokar, U.S. Nuclear Regulatory Commission

W. J. Bailey, M. E. Cunningham

Pacific Northwest Laboratory

Richland, WA 99352

Prepared for

Division of Systems Integration

Office of Nuclear Reactor Regulation

U.S. Nuclear Regulatory Commission

Washington, D.C. 20555

NRC FIN B2320 



\section{ABSTRACT}

This annual report, the second in a series, provides a brief description of fuel performance in commercial nuclear power plants. Brief summaries are given of fuel surveillance programs, fuel performance problems, and fuel design changes. References to additional, more detailed, information and related NRC evaluation are provided. 



\section{CONTENTS}

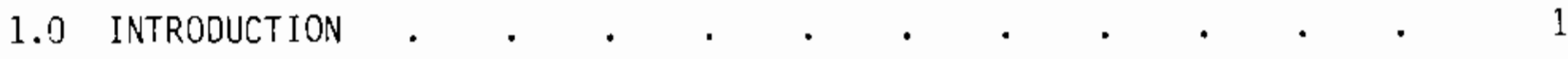

2.0 FUEL SURVEILLANCE PROGRAMS AND OPERATING EXPERIENCE $\quad$. . . . 2

2.1 Fuel Surveillance Requirements . . . . . . . . 2

2.2 Fuel Surveillance Program and Experience Sumary . . . . 6

2.2.1 Babcock \& Wilcox Company (B\&) . . . . . . . . 6

2.2.2 Combustion Engineering, Inc. (C-E) . . . . 6

2.2.3 Exxon Nuclear Company, Inc. (ENC) . . . . . . 9

2.2.4 General Electric Company (GE) • . . . . . 9

2.2.5 Westinghouse Electric Corporation $(\underline{W})$. . . . . 11

2.2.6 Electric Power Research Institute (EPRI) . . . 14

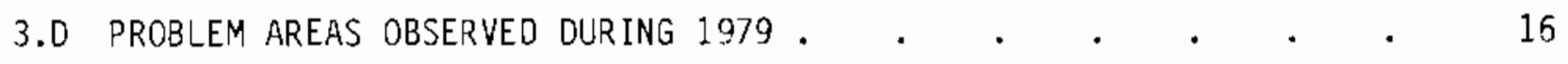

3.1 PWR Baffle Jetting . . . . . . . . . . . . . . . 16

3.2 BWR Control Blade Cracking . . . . . . . . . . . . 18

3.3 PWR Stainless Steel Cladding Cracking . . . . . . . . 19

3.4 BWR Water Rod Lower End Plug Wear . . . . . . . 21

3.5 PWR Guide Tube Wear . . . . . . . . . . 22

3.6 Crud and Corrosion . . . . . . . . . . . . . . 23

3.6.l Maine Yankee (PWR) . . . . . . . . . . . 23

3.6 .2 Vermont Yankee $(B W R)$. . . . . . . . . 23

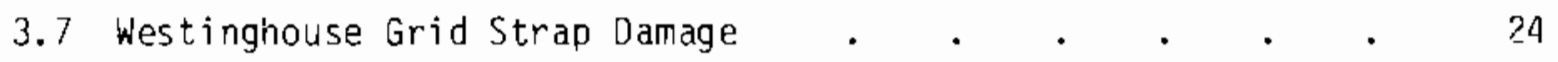

3.8 Westinghouse Control Spider Rodiet Failures . . . . . 25

3.9 Extensive Core Damage - Three Mile Island Unit 2 (PWR) . • 25

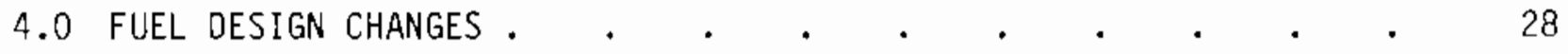

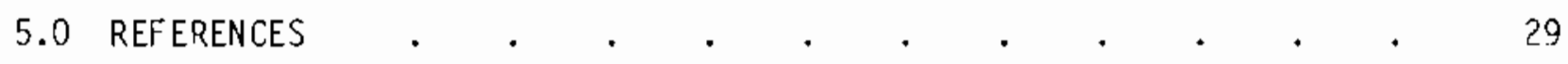





\section{TABLES}

1 Typical Fuel Assembiy Parameters . . . . . . . 3-5

2 Major Fuel Performance Programs: Status Through 1970 . . . 7

3 Summary of Babcock \& Wilcox Fuel Rod Performance for 1979 . . 8

4 Summary of Combusion Engineering Fuel Irradiated and/or Discharged in 1979 . . . . . . . . . . . 10

5 General Electric BWR/2-5 Fuel Experience Sumary (1/1/80) . . 11

6 General Electric Fuel Surveillance Programs . . . . . 12

7 Westinghouse High Burnup Fuel Operating Experience as of
June $10,1980.0$. 



\subsection{INTRODUCTION}

Monitoring of in-reactor performance of nuclear fuel in commercial 1 ightwater power reactors provides important feedback for safety considerations and licensing procedures. Interest in a publicly available summary of in-reactor fuel performance has been expressed by members of the public, governing and advisory bodies, and the Nuclear Regulatory Commission (NRC) staff. Therefore, a series of annual reports, of which this is the second, has been implemented to provide such a summary.

As noted in the first report of this annual series, NUREG-0633 (Ref. 1), the Atomic Energy Commission (AEC) and then the NRC have requested operating nuclear reactor fuel performance details through the reporting requirements of Regulatory Guide 1.16 (Ref. 2). However, the material covered in these reports has changed over the years. The 1971 version of the guide requested that a summary of fuel performance characteristics be given in semiannual operating reports and that special topical reports be used for fuel inspection details. By 1975 though, oniy the abnormal degradation of fuel cladding and the indication of failed fuel were reportable items. In 1977 the requirements were further reduced to cover only the abnormal degradation of fuel cladding, and the requirement for an annual operating report was dropped. Moreover, the NUREG series entitled "Nuclear Power Plant Operating Experience" (Refs 3-5) does not address either normal operation serveillance results, generic problems, or design trends.

Therefore, it is the primary intent of this report series to identify the on-going surveillance programs, to summarize their results, and to report on generic problems that are of concern during the reporting period. In so doing, every attempt is made to provide a traceable path of references so that the reader can acquire a greater level of detail than is provided in the annual summary.

This report, though focusing on fuel operating experience during calendar year 1979, includes some overlap with previous years. For those problems first encountered prior to 1979, the pre-1979 information will be included for the sake of continuity. In addition, information received or action taken in early 1980 will be included if pertinent to the discussion of problem areas. 


\subsection{FUEL SURVE ILLANCE PROGRAMS AND OPEERAIING EXPERI ENCE}

This section presents the basic requirements of fuel surveillance programs, followed by a sumary of the current programs and nperating experienco.

\subsection{FUEL SURVE IILLANCE REQUIREMENTS}

Section 4.2, Fuel System Desian, of the Standard Review Plan (Ref. 5) requires that testing, inspection, and fuel surveillance plans be submitted and reviawed for eaci plant. These plans should include preirradiation verification of cladding integrity, fuel system dimensions, fuel enrichment, hurnable poison concentration, and absorber composition. Postirradiation sirveillance plans are dependent on whether the fuel design is an existing or new design, and if the fuel exhijited any inusua? jehavior or characteristics. These plans are then referenced and/or summarized in the plant s safety analysis report (SAR). An example of a required fuel surveillance program is provided in Reference 7.

To sumarize the current commercial light-water reactor (LWR) fuel rod designs for use in pressurized water reactors (PWR;) and boiling water reactors (BWRs), Table 1 lists typical fuel assombly narameters (a) and operating conditions. The newer fuel rod designs are those with smaller fuel rod diameters and more rods per assembly. With this design, the tota? assombly power is maintained while the individual rods are operated at lower powers and temperatures. This design change is expected to aid in improving the irradiation behavior of commercial LWR fuel by reducing fission gas relaase from the fuel and by reducing the mechanical interation between the fuel and claditing. For example, according to sample calculations, the shift from a $7 \times 7$ to an $8 \times 3$ rod array in BWR fuel produces a reduction in fiss on gas release of about $15 \%$ at high burnups: from 20 to $13 \%$ at $2592 \mathrm{GJ} / \mathrm{kgJ}(30,000 \mathrm{MWd} / \mathrm{MTJ})$ and 45 to $30 \%$ at $3888 \mathrm{GJ} / \mathrm{kgU}(45,000 \mathrm{l} / \mathrm{Wd} / \mathrm{MTU})$.

(a) The terms "fuel assembly" and "fuel bundle" are used interchangeably by the nuclear industry.

(b) $\mathrm{GJ} / \mathrm{kgU}=$ gigajoule/kilogram of heavy metal ( $\mathrm{e.g}$, uranium); MWd $/$ MTU = number of megawatt days of thermal energy released by fuel containing one metric ton $\left(10^{6}\right)$ of heavy-metal atoms (e.g., uranium). 
TABLE 1. Typical Fuel Assembiy Parameters

\begin{tabular}{|c|c|c|c|c|c|c|c|c|c|c|c|c|}
\hline VENDOR & $B \& W$ & $B \& W$ & $C-E$ & $C-E$ & h & i․ & b & - ENC & ENC & $\mathrm{GE}$ & $\mathrm{GE}$ & GE \\
\hline Fue? Rod Array & $15 \times 15$ & $17 \times 17$ & $14 \times 14$ & $16 \times 16$ & $14 \times 14$ & $15 \times 15$ & $17 \times 17$ & $15 \times 15$ & $8 \times 8$ & $7 \times 7$ & $8 \times 8$ & $8 \times 8 R$ \\
\hline Reactor Type & PWR & PW'R & PWR & PWR & PWR & PWR & PWR & PWR & BWR & BWR & $8 W R$ & BWR \\
\hline Assemblies per Core & 177 & 205 & 217 & 177 & 171 & 193 & 193 & 193 & 560 & 764 & 560 & 560 \\
\hline $\begin{array}{l}\text { Fuel Rod Locations } \\
\text { Per Assembly }\end{array}$ & 225 & 289 & 196 & 256 & 196 & 225 & 289 & 225 & 64 & 49 & 64 & 64 \\
\hline $\begin{array}{l}\text { Fuel Rods } \\
\text { Per Assembly }\end{array}$ & 208 & 264 & 176 & 236 & 179 & 204 & 264 & 204 & 60 & 49 & 63 & 62 \\
\hline $\begin{array}{l}\text { Empty Locations } \\
\text { Per Assembly }\end{array}$ & 17 & 25 & 5 & 5 & 17 & $7 \mathrm{i}$ & 25 & 21 & 4 & NONE & 1 & 2 \\
\hline $\begin{array}{l}\text { Rod Pitch, } \\
m m \text { (in.) }\end{array}$ & $\begin{array}{l}14.4 \\
(0.568)\end{array}$ & $\begin{array}{l}12.7 \\
(0.501)\end{array}$ & $\begin{array}{l}14.7 \\
(0.580)\end{array}$ & $\begin{array}{l}i 2.9 \\
(0.5063)\end{array}$ & $\begin{array}{l}14.1 \\
(0.556)\end{array}$ & $\begin{array}{l}14.3 \\
(0.563)\end{array}$ & $\begin{array}{l}12.6 \\
(0.496)\end{array}$ & $\begin{array}{l}14.3 \\
(0.563)\end{array}$ & $\begin{array}{l}16.3 \\
(0.842)\end{array}$ & $\begin{array}{l}18.7 \\
(0.738)\end{array}$ & $\begin{array}{l}16.3 \\
(0.640)\end{array}$ & $\begin{array}{l}16.3 \\
(0.640)\end{array}$ \\
\hline $\begin{array}{l}\text { System Pressure, } \\
\text { MPa (psia) }\end{array}$ & $\begin{array}{l}15.2 \\
(2200)\end{array}$ & $\begin{array}{l}15.5 \\
(2250)\end{array}$ & $\begin{array}{l}15.5 \\
(2250)\end{array}$ & $\begin{array}{l}15.5 \\
(2250)\end{array}$ & $\begin{array}{l}15.5 \\
(2250)\end{array}$ & $\begin{array}{l}15.5 \\
(2250)\end{array}$ & $\begin{array}{l}15.5 \\
(2250)\end{array}$ & $\begin{array}{l}15.5 \\
(2250)\end{array}$ & $\begin{array}{l}7.14 \\
(1035)\end{array}$ & $\begin{array}{l}7.14 \\
(1035)\end{array}$ & $\begin{array}{l}7.14 \\
(1035)\end{array}$ & $\begin{array}{l}7.14 \\
(1035)\end{array}$ \\
\hline $\begin{array}{l}\text { Core Average Power } \\
\text { Density, } \mathrm{kW} / 1 \text { iter }\end{array}$ & 90.0 & 101.6 & 78.5 & 96.4 & 95.6 & 98.1 & 104.7 & 98.1 & 40.57 & 50.732 & 50.51 & 49.15 \\
\hline $\begin{array}{l}\text { Average LHGR, } \\
\mathrm{kW} / \mathrm{M}(\mathrm{kW} / \mathrm{ft})\end{array}$ & $\begin{array}{l}20.0 \\
(6.105)\end{array}$ & $\begin{array}{l}17.8 \\
(5.43)\end{array}$ & $\begin{array}{l}20.0 \\
(6.09)\end{array}$ & $\begin{array}{l}17.5 \\
(5.34)\end{array}$ & $\begin{array}{l}20.3 \\
(6.20)\end{array}$ & $\begin{array}{l}22.0 \\
(6.70)\end{array}$ & $\begin{array}{l}17.8 \\
(5.44)\end{array}$ & $\begin{array}{l}22.0 \\
(6.70)\end{array}$ & $\begin{array}{l}15.2 \\
(4.63)\end{array}$ & $\begin{array}{l}23.1 \\
(7.049)\end{array}$ & $\begin{array}{l}17.9 \\
(5.45)\end{array}$ & $\begin{array}{l}17.7 \\
(5.38)\end{array}$ \\
\hline $\begin{array}{l}\text { Axial Peak in an } \\
\text { Average Rod, } \\
\mathrm{kW} / \mathrm{M}(\mathrm{kW} / \mathrm{ft})\end{array}$ & $\begin{array}{l}24.00 \\
(7.33)\end{array}$ & $\begin{array}{l}21.36 \\
(6.52)\end{array}$ & $\begin{array}{l}24.00 \\
(7.31)\end{array}$ & $\begin{array}{l}21.00 \\
(6.41)\end{array}$ & $\begin{array}{l}24.36 \\
(7.44)\end{array}$ & $\begin{array}{l}26.40 \\
(8.04)\end{array}$ & $\begin{array}{l}2.1 .36 \\
(6.53)\end{array}$ & $\begin{array}{l}26.40 \\
(8.04)\end{array}$ & $\begin{array}{l}18.24 \\
(6.02)\end{array}$ & $\begin{array}{l}27.72 \\
(9.16)\end{array}$ & $\begin{array}{l}21.48 \\
(7.09)\end{array}$ & $\begin{array}{l}21.24 \\
(6.99)\end{array}$ \\
\hline $\begin{array}{l}\operatorname{Max} . \text { Peak LHGR, } \\
\mathrm{kw} / \mathrm{M}(\mathrm{kw} / \mathrm{ft})\end{array}$ & $\begin{array}{l}62.4 \\
(19.03)\end{array}$ & $\begin{array}{l}48.4 \\
(14.74)\end{array}$ & $\begin{array}{l}53.5 \\
(16.3)\end{array}$ & $\begin{array}{l}42.7 \\
(13.0)\end{array}$ & $\begin{array}{l}56.8 \\
(17.3)\end{array}$ & $\begin{array}{l}61.7 \\
18.8)\end{array}$ & $\begin{array}{l}44.6 \\
(13.6)\end{array}$ & $\begin{array}{l}51.9 \\
\{15.83\}\end{array}$ & $\begin{array}{l}47.6 \\
(14.5)\end{array}$ & $\begin{array}{l}60.2 \\
(18.35)\end{array}$ & $\begin{array}{l}44.0 \\
(13.4)\end{array}$ & $\begin{array}{l}44.0 \\
(13.4)\end{array}$ \\
\hline $\begin{array}{l}\text { Max. Fue }) \text { Temperature, } \\
{ }^{\circ} \mathrm{C}\left(\mathrm{O}^{\circ}\right)\end{array}$ & $\begin{array}{l}2300 \\
(4170)\end{array}$ & $\begin{array}{l}2020 \\
(3670)\end{array}$ & $\begin{array}{l}2140 \\
(3890)\end{array}$ & $\begin{array}{l}1880 \\
(3420)\end{array}$ & $\begin{array}{l}2260 \\
(4100)\end{array}$ & $\begin{array}{l}2340 \\
(4250)\end{array}$ & $\begin{array}{l}1870 \\
(3400)\end{array}$ & $\begin{array}{l}2200 \\
(3997)\end{array}$ & $\begin{array}{l}2040 \\
(3700)\end{array}$ & $\begin{array}{l}2440 \\
(4430)\end{array}$ & $\begin{array}{l}1830 \\
(3325)\end{array}$ & $\begin{array}{l}1890 \\
(3435)\end{array}$ \\
\hline
\end{tabular}


TABLE 1. (Continued)

\begin{tabular}{|c|c|c|c|c|c|c|c|c|c|c|c|c|}
\hline VENOOR & B\&W & $B \& W$ & $C-E$ & $C-E$ & & $\underline{H}$ & Hi & ENC & ENC & GE & GE & $\mathrm{GE}$ \\
\hline $\begin{array}{c}\text { Core Average } \\
\text { Enr ichment, } \\
\text { wt } x \text { 235y }\end{array}$ & 2.57 & 2.96 & 2.35 & 2.36 & 2.90 & 2.80 & 2.60 & 3.02 & 2.65 & 2.19 & 1.80 & 1.99 \\
\hline Fue I Rod Array & $15 \times 15$ & $17 \times 17$ & $14 \times 14$ & $16 \times 16$ & $14 \times 14$ & $15 \times 15$ & $17 \times 17$ & $15 \times 15$ & $8 \times 8$ & $7 \times 7$ & $8 \times 8$ & $8 \times 8$ \\
\hline $\begin{array}{l}\text { Max. Local } \\
\text { Exposure, } \\
\text { GJ/kgU } \\
\text { (MWd/MTU) }\end{array}$ & $\begin{array}{l}4752 \\
(55,000)\end{array}$ & $\begin{array}{l}4752 \\
(55,000)\end{array}$ & $\begin{array}{l}4320 \\
(50,000)\end{array}$ & $\begin{array}{l}4752 \\
(55,000)\end{array}$ & $\begin{array}{l}4320 \\
(50,000)\end{array}$ & $\begin{array}{l}4320 \\
(50,000)\end{array}$ & $\begin{array}{l}4320 \\
(50,000)\end{array}$ & $\begin{array}{l}4104 \\
(47,500)\end{array}$ & $\begin{array}{l}3024 \\
(35,000)\end{array}$ & $\begin{array}{l}3456 \\
(40,000)\end{array}$ & $\begin{array}{l}3456 \\
(40,000)\end{array}$ & $\begin{array}{l}3888 \\
(45,000)\end{array}$ \\
\hline $\begin{array}{l}\text { Cladding } \\
\text { Material }\end{array}$ & $2 r y-4$ & $2 r y-4$ & $2 r y-4$ & $\operatorname{2ry}-4$ & $\operatorname{Zry}-4$ & $\operatorname{lry}-4$ & $\operatorname{Zry}-4$ & Zry-4 & $\operatorname{Zry}-2$ & $2 r y-2$ & $\operatorname{lr} y-2$ & $2 r y-2$ \\
\hline $\begin{array}{l}\text { Fue } 1 \text { Rod } \\
\text { Length, } \\
\text { m(in.) }\end{array}$ & $\begin{array}{l}3.89 \\
(153.13)\end{array}$ & $\begin{array}{l}3.86 \\
(152.13)\end{array}$ & $\begin{array}{l}3.71 \\
(145.9)\end{array}$ & $\begin{array}{l}4.09 \\
(161.02)\end{array}$ & $\begin{array}{l}3.87 \\
(152.36)\end{array}$ & $\begin{array}{l}3.80 \\
(149.7)\end{array}$ & $\begin{array}{l}3.85 \\
(151.6)\end{array}$ & $\begin{array}{l}3.86 \\
(152.0)\end{array}$ & $\begin{array}{l}3.99 \\
(156.92)\end{array}$ & $\begin{array}{l}4.09 \\
(161.1)\end{array}$ & $\begin{array}{l}4.09 \\
(161.1)\end{array}$ & $\begin{array}{l}4.20 \\
(185.4)\end{array}$ \\
\hline $\begin{array}{l}\text { Active Fuel } \\
\text { Height, } \\
m \text { (in.) }\end{array}$ & $\begin{array}{l}3.66 \\
(144)\end{array}$ & $\begin{array}{l}3.63 \\
(143)\end{array}$ & $\begin{array}{l}3.47 \\
(136.7)\end{array}$ & $\begin{array}{l}3.81 \\
(150)\end{array}$ & $\begin{array}{l}3.66 \\
(144)\end{array}$ & $\begin{array}{l}3.66 \\
(144)\end{array}$ & $\begin{array}{l}3.65 \\
(143.7)\end{array}$ & $\begin{array}{l}3.66 \\
(144)\end{array}$ & $\begin{array}{l}3.66 \\
(144)\end{array}$ & $\begin{array}{l}3.66 \\
(144)\end{array}$ & $\begin{array}{l}3.71 \\
\{146\}\end{array}$ & $\begin{array}{l}3.81 \\
(150)\end{array}$ \\
\hline $\begin{array}{l}\text { Pienum Length, } \\
\text { m (in.) }\end{array}$ & $\begin{array}{l}0.29 \\
(11.27)\end{array}$ & $\begin{array}{l}0.24 \\
(9.52)\end{array}$ & $\begin{array}{l}0.22 \\
(8.6)\end{array}$ & $\begin{array}{l}0.25 \\
(10.00)\end{array}$ & $\begin{array}{l}0.18 \\
(6.99)\end{array}$ & $\begin{array}{l}0.21 \\
(8.2)\end{array}$ & $\begin{array}{l}0.16 \\
(6.3)\end{array}$ & $\begin{array}{l}0.17 \\
(6.8)\end{array}$ & $\begin{array}{l}0.27 \\
(10.63)\end{array}$ & $\begin{array}{l}0.41 \\
(16.0)\end{array}$ & $\begin{array}{l}0.36 \\
(14.0)\end{array}$ & $\begin{array}{l}0.25 \\
(10.0)\end{array}$ \\
\hline $\begin{array}{l}\text { Fue l Rod } 00 \text {, } \\
\text { mm (in.) }\end{array}$ & $\begin{array}{l}10.92 \\
(0.430)\end{array}$ & $\begin{array}{l}9.63 \\
(0.379)\end{array}$ & $\begin{array}{l}11.18 \\
(0.440)\end{array}$ & $\begin{array}{l}9.70 \\
(0.382)\end{array}$ & $\begin{array}{l}10.72 \\
(0.42 .2)\end{array}$ & $\begin{array}{l}10.72 \\
(0.422)\end{array}$ & $\begin{array}{l}9.50 \\
(0.374)\end{array}$ & $\begin{array}{l}10.77 \\
(0.424)\end{array}$ & $\begin{array}{l}12.74 \\
(0.5015)\end{array}$ & $\begin{array}{l}14.30 \\
(0.563)\end{array}$ & $\begin{array}{l}12.52 \\
(0.493)\end{array}$ & $\begin{array}{l}12.27 \\
(0.483)\end{array}$ \\
\hline $\begin{array}{l}\text { Cladding Io, } \\
\text { mm (in.) }\end{array}$ & $\begin{array}{l}9.58 \\
(0.377)\end{array}$ & $\begin{array}{l}8.43 \\
(0.332)\end{array}$ & $\begin{array}{l}9.86 \\
(0.388)\end{array}$ & $\begin{array}{l}8.43 \\
(0.332)\end{array}$ & $\begin{array}{l}9.48 \\
(0.3734)\end{array}$ & $\begin{array}{l}9.48 \\
(0.3734)\end{array}$ & $\begin{array}{l}8.36 \\
(0.329)\end{array}$ & $\begin{array}{l}9.25 \\
(0.364)\end{array}$ & $\begin{array}{l}10.91 \\
(0.4295)\end{array}$ & $\begin{array}{l}12.68 \\
(0.499)\end{array}$ & $\begin{array}{l}10.80 \\
(0.425)\end{array}$ & $\begin{array}{l}10.64 \\
(0.419)\end{array}$ \\
\hline $\begin{array}{l}\text { Cladding } \\
\text { Thickness, } \\
\text { mm (in.) }\end{array}$ & $\begin{array}{l}0.673 \\
(0.0265)\end{array}$ & $\begin{array}{l}0.597 \\
(0.0235)\end{array}$ & $\begin{array}{l}0.660 \\
(0.026)\end{array}$ & $\begin{array}{l}0.635 \\
(0.025)\end{array}$ & $\begin{array}{l}0.617 \\
(0.0243)\end{array}$ & $\begin{array}{l}0.617 \\
(0.0243)\end{array}$ & $\begin{array}{l}0.572 \\
(0.0225)\end{array}$ & $\begin{array}{l}0.762 \\
(0.030)\end{array}$ & $\begin{array}{l}0.914 \\
(0.036)\end{array}$ & $\begin{array}{l}0.813 \\
(0.032)\end{array}$ & $\begin{array}{l}0.864 \\
(0.034)\end{array}$ & $\begin{array}{l}0.813 \\
(0.032)\end{array}$ \\
\hline $\begin{array}{l}\text { Diametra l Gap, } \\
\text { micron (mil) }\end{array}$ & $\begin{array}{l}178 \\
(7.0)\end{array}$ & $\begin{array}{l}203 \\
(8.0)\end{array}$ & $\begin{array}{l}216 \\
(8.5)\end{array}$ & $\begin{array}{l}178 \\
(7.0)\end{array}$ & $\begin{array}{l}190 \\
(7.5)\end{array}$ & $\begin{array}{l}190 \\
(7.5)\end{array}$ & $\begin{array}{l}165 \\
(6.5)\end{array}$ & $\begin{array}{l}190 \\
(7.5)\end{array}$ & $\begin{array}{l}254 \\
\{10.0\}\end{array}$ & $\begin{array}{l}305 \\
(12.0)\end{array}$ & $\begin{array}{l}229 \\
(9.0)\end{array}$ & $\begin{array}{l}229 \\
(9.0)\end{array}$ \\
\hline
\end{tabular}


TABLE 1. (Continued)

\begin{tabular}{|c|c|c|c|c|c|c|c|c|c|c|c|c|c|}
\hline \multirow{4}{*}{$\Omega$} & VENDOR & $B \& W$ & B\&W & $C-E$ & $C-E$ & HII & b. & 直 & ENC & ENC & $G E$ & GE & GE \\
\hline & $\begin{array}{c}\text { Fue } 1 \text { Pellet } \\
\text { Diameter, } \\
\text { mm (in.) }\end{array}$ & $\begin{array}{l}9.40 \\
(0.370)\end{array}$ & $\begin{array}{l}8.23 \\
(0.324)\end{array}$ & $\begin{array}{l}9.64 \\
(0.3795)\end{array}$ & $\begin{array}{l}8.26 \\
(0.325)\end{array}$ & $\begin{array}{l}9.29 \\
(0.3659)\end{array}$ & $\begin{array}{l}9.29 \\
(0.3659)\end{array}$ & $\begin{array}{l}8.19 \\
(0.3225)\end{array}$ & $\begin{array}{l}9.06 \\
(0.3565)\end{array}$ & $\begin{array}{l}10.66 \\
(0.4195)\end{array}$ & $\begin{array}{l}12.37 \\
(0.487)\end{array}$ & $\begin{array}{l}10.57 \\
(0.416)\end{array}$ & $\begin{array}{l}10.41 \\
(0.410)\end{array}$ \\
\hline & $\begin{array}{l}\text { Fuel Pellet } \\
\text { Length, } \\
\text { mm (in.) }\end{array}$ & $\begin{array}{l}17.78 \\
(0.700)\end{array}$ & $\begin{array}{l}9.53 \\
(0.376)\end{array}$ & $\begin{array}{l}16.51 \\
(0.650)\end{array}$ & $\begin{array}{l}9.91 \\
(0.390)\end{array}$ & $\begin{array}{l}15.24 \\
\{0.600\}\end{array}$ & $\begin{array}{l}15.24 \\
(0.600)\end{array}$ & $\begin{array}{l}13.46 \\
(0.530)\end{array}$ & $\begin{array}{l}6.93 \\
(0.273)\end{array}$ & $\begin{array}{l}8.13 \\
(0.320)\end{array}$ & $\begin{array}{l}12.70 \\
(0.500)\end{array}$ & $\begin{array}{l}10.67 \\
(0.420)\end{array}$ & $\begin{array}{l}10.41 \\
(0.410)\end{array}$ \\
\hline & $\begin{array}{l}\text { Fuel Pellet } \\
\text { Density, } \\
\text { xid }\end{array}$ & 94 & 94 & 94.75 & 95 & 94 & 95 & 95 & 94 & 95 & 95 & 95 & 95 \\
\hline
\end{tabular}




\subsection{FUEL SURVEILLANCE PROGRAM AND EXPERIENCE SUMMARY}

Table 2 provides an up-dated listing of the major fuel surveillance programs for each fuel vendor. Depending on the procram, nondestructive or destructive examination techniques, or both, are used. Some of these programs are jointly sponsored with participation by the flel vendor, utility, utility groups, and the Electric Power Research Institute (EPRI). The 1isting of a given program under a vendor heading is not, therefore, intended to imply that that vendor is the sole sponsor. The project details listed in Table 2 reflect the NRC's current understanding of the programs and are subject to change. A brief synopis of each vendor's program and EPRI's involvement is provided in the following subsections.

\subsubsection{Babcock \& Wi Icox Company (B\&W)}

A summary of Babcock \& Wilcox fuel rod experience for 3979 is provided in Table 3 (Refs. 8 and 9). As shown, most of the rods irradiated were of the older $15 \times 15$ Mark B type. The number of leaking rods ${ }^{(a)}$ was estimated from the equilibrium coolant radioiodine (Iodine-131) behavior during full-power operation. Because of uncertainties associated with the location and nature of probable leaking rods, the number of leaking rods shown represents only a reasonable estimate of the fuel defect status. Based on the estimated number of rods irradiated in 1979 and the estimated number of leaking rods (discharged and inreactor on Dec. 3], 1979), the defect rate was $20.04 \%$. Due to the relatively smal1 fraction of $17 \times 17$ fuel in operation with $15 \times 15$ fuel, the differentiation of probable leaking rods among the two types was not made. Seven B\&W fuel surveit]ance reports (Refs. 10-16) were issued in 1979.

\subsubsection{Combustion Engineering, Inc. (C-E)}

During 1979, Combustion Engineering fuel was irradiated in seven of their eight reactors. Six of the reactors use a $14 \times 14$ fuel assembly design, while Palisades uses a $15 \times 15$ design. The eighth Combustion Engineering plant is Arkansas Nuclear One-Unit 2 (ANO-2) which uses a new $16 \times 16$ design that is

(a) Leading fuel rods refers to rods which are releasing fission products to the reactor coolant. 
TABLE 2. Major Fuel Performance Programs: Status Through 1970

\begin{tabular}{|c|c|c|c|c|c|}
\hline Vendor & Fuel Type (a) & $\begin{array}{l}\text { Power } \\
\text { Plant }\end{array}$ & $\begin{array}{c}\text { Planned No. } \\
\text { of Operating } \\
\text { Cycles } \\
\end{array}$ & $\begin{array}{l}\text { Scheduled } \\
\text { Completion }\end{array}$ & $\begin{array}{c}\text { Interim } \\
\text { Inspections } \\
\text { to Date } \\
\end{array}$ \\
\hline $\begin{array}{l}\text { Babcock \& } \\
\text { Wilcox }\end{array}$ & $\begin{array}{l}15 \times 15 \\
15 \times 15 \\
15 \times 15(\mathrm{~b}) \\
15 \times 15(\mathrm{c}) \\
15 \times 15(\mathrm{~d}) \\
15 \times 15(\mathrm{e}) \\
15 \times 15(\mathrm{f}) \\
17 \times 17(\mathrm{LTA})\end{array}$ & $\begin{array}{l}\text { Oconee-1 } \\
\text { Oconee-1 } \\
\text { ANO-1 } \\
\text { Rancho Seco } \\
\text { Oconee-2 } \\
\text { Oconee-2 } \\
\text { Oconee-2 } \\
\text { Oconee-2 }\end{array}$ & $\begin{array}{l}3 \text { cycles } \\
4 \text { cycles } \\
3 \text { cycles } \\
3 \text { cycles } \\
4 \text { cycles } \\
3 \text { cycles } \\
3 \text { cycles } \\
3 \text { cycles }\end{array}$ & $\begin{array}{l}1978 \\
1980 \\
1988 \\
1986 \\
1980 \\
1981 \\
1983 \\
1981\end{array}$ & $\begin{array}{c}\text { Completed } \\
2 \\
\text { None } \\
\text { None } \\
3 \\
2 \\
\text { None } \\
2\end{array}$ \\
\hline $\begin{array}{l}\text { Combustion } \\
\text { Engineering }\end{array}$ & $\begin{array}{l}14 \times 14 \\
14 \times 14(\mathrm{LTA}) \\
14 \times 14(\mathrm{LTA}) \\
16 \times 16\end{array}$ & $\begin{array}{l}\text { Calvert Cliffs-1 } \\
\text { Calvert Cl iffs-1 } \\
\text { Fort Calhoun-1 } \\
\text { ANO-2 }\end{array}$ & $\begin{array}{l}3 \text { cycles } \\
3 \text { cycles }\end{array}$ & $\begin{array}{c}1980 / 1982 \\
1981\end{array}$ & 2 \\
\hline $\begin{array}{l}\text { Exxon } \\
\text { Nuclear }\end{array}$ & $\begin{array}{l}15 \times 15 \\
8 \times 8\end{array}$ & $\begin{array}{l}\text { H. B. Robinson-2 } \\
\text { Oyster Creek }\end{array}$ & $\begin{array}{l}4 \text { cycles } \\
5 \text { cycles }\end{array}$ & $\begin{array}{l}1980 \\
1982\end{array}$ & $\begin{array}{l}1 \\
1\end{array}$ \\
\hline $\begin{array}{l}\text { Generd } \\
\text { Electric }\end{array}$ & $\begin{array}{l}7 \times 7 \quad\left(\mathrm{MO}_{2}\right) \\
7 \times 7 \quad\left(\mathrm{MO}_{2}\right) \\
8 \times 8 \\
8 \times 8 \\
8 \times 8 \mathrm{R}(\mathrm{LTA}) \\
8 \times 8 \mathrm{R}(\mathrm{LTA}) \\
8 \times 8 \mathrm{R}(\mathrm{PP}) \\
8 \times 8 \mathrm{R}(\mathrm{PP}) \\
\text { Barrier Clad }\end{array}$ & $\begin{array}{l}\text { Quad Cities-1 } \\
\text { Quad Cities-1 } \\
\text { Quad Cities-1 } \\
\text { Monticello } \\
\text { Peach Bottom-2 } \\
\text { Vermont Yankee } \\
\text { Peach Bottom-3 } \\
\text { Quad Cities-1 }\end{array}$ & $\begin{array}{l}5 \text { cycles } \\
5 \text { cycles } \\
5 \text { cycles } \\
5 \text { cycles } \\
5 \text { cycles }\end{array}$ & $\begin{array}{c}1982 \\
1982 \\
1980 \\
1982 \\
1983 \\
1979(\mathrm{~g}) \\
1982 \\
1984\end{array}$ & $\begin{array}{c}2 \\
3 \\
2 \\
1 \\
\text { None }\end{array}$ \\
\hline Westinghouse & $\begin{array}{l}14 \times 14 \\
15 \times 15 \\
17 \times 17(\mathrm{LTA}) \\
17 \times 17(\mathrm{LTA}) \\
17 \times 17(\text { OFA-Demo }) \\
17 \times 17(\text { OFA-Demo })\end{array}$ & $\begin{array}{l}\text { Point Beach-1 } \\
\text { Zion-1 } \\
\text { Surry-1 } \\
\text { Surry-2 } \\
\text { Farley-1 } \\
\text { Salem-1 }\end{array}$ & $\begin{array}{l}3 \text { cycles } \\
3 \text { cycles } \\
2 \text { cycles } \\
4 \text { cycles }\end{array}$ & $\begin{array}{l}1978 \\
1978 \\
1976 \\
1980\end{array}$ & $\begin{array}{l}\text { Campleted } \\
2 \\
\text { Completed } \\
3\end{array}$ \\
\hline
\end{tabular}

(a) $L T A=$ lead test assembly, $\mathrm{MO}_{2}=$ mixed oxide $\left(\mathrm{UO}_{2}-\mathrm{Pu0_{2 }}\right)$ fuel, $\mathrm{R}=$ retrofit fuel design, $\mathrm{PP}=$ prepressurized $(3 \mathrm{~atm}), 0 F A-D e m o=$ Demonstration Opt imized Fuel Assemblies.

(b) Lead test assemblies of an advanced $15 \times 15$ extended burnup design.

(c) Current-design $15 \times 15$ assemblies containing axially-bianketed fuel columns.

(d) Current-design $15 \times 15$ assemblies with special Zircaloy cladding materials and EPRI creep collapse specimen clusters.

(e) Current-design $15 \times 15$ assemblies with lifted rods and cladding having a known spiral eccentricity.

(f) Current-design $15 \times 15$ assembly utilizing low absorption spacer grid material (Zircaloy-4).

(g) Discharged in September 1979. 
TABLE 3. Sumary of Babcock \& Wiicox Fuel Rod Performance for 1979(a)

Fue ] Rod Type

1. Cumulative Number of Rods

Irradiated through Dec. 1979:

2. Total Number of Rods Irradiated in 1979

3. Number of Irradiated Rods In-Core on December 31, 1979 a. Maximum Rod - Average Burnup of
Rods In-Core, GJ/kgU (MWD/MTU)
b. Mean Rod - Average Burnup of Rods In-Core, GJ/kgU (MWd/MTU)

4. Number of Rods Discharged in 1979

$\frac{15 \times 15}{52.5,408}$

$$
332,384
$$

$\frac{17 \times 17}{1,056}$

1,056

1,056

$$
\begin{array}{cc}
268,736 & 1,056 \\
3,262(37,760) & 2,056 \quad(23,800) \\
1,204(13,940) & 1,892(21,900)
\end{array}
$$

63,648

0
a. Maximum Rod - Average Burnup of Rods Discharged, GJ/kgU (MWd/MTU)
$3,546(41,037)$

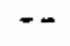
b. Mean Rod - Average Burnup of Rods Discharged, GJ/kgJ (MWd/MTU)
$1,908(22,084)$

5. Estimated Number of Leaking Rods:
a. In-Core on Dec. 31, 1979
94
b. Discharged in 1979
35
c. Generated in 1979
80 (a) Connecticut Yankee and Three Mile Island Unit 2 are excluded from this
tabulation. 
the precursor to Combustion Engineering's standardized System $80^{(B)}$ design. Since comercial operation of ANO-2 did not begin until March 1980, data for the reactor are not included here.

Table 4 summarizes the irradiation exposure and the estimated number of leaking rods in each reactor. Though five of the reactors were shut down for refueling in 1979, none of the utilities felt that sipping of the fuel assemblies was necessary (Ref. 17). Therefore, the estimate of leaking fuel rods is based on the level of iodine-131 in the reactor coolant (Ref. 18). Based on the estimated number of leaking rods (18 out of 225,000 ), the defect rate is less than $0.01 \%$, as of February 1, 1979 .

\subsubsection{Exxon Nuclear Company, Inc. (ENC)}

Exxon Nuclear is currently the sole domestic supplier of both BWR and PWR fuel. Since Exxon Nuclear is not a power plant vendor, its fuel is introduced as reloads. Although Exxon Nuclear reload fuel designs are basically similar to the fuel being replaced, Exxon Nuclear performs its own design analysis, and Exxon Nuclear fuel has its own unique design features. For example, Exxon Nuclear cladding is slightly thicker than others (see Table 1), and all Exxon Nuclear assemblies are reconstitutable.

As of December 1979, Exxon Nuclear had approximately 2190 fuel assembiies operating in various domestic and foreign BWRs and PWRs, according to $G$. $F$. Owsley (Ref. 19). Also, approximatelv 370 fuel assemblies have achieved design burnups and have been discharged to spent fuel pools. Peak assembly burnups of $\sim 2722 \mathrm{GJ} / \mathrm{kgU}(\sim 31,500 \mathrm{MWd} / \mathrm{MTU})$ have been achieved. Nine fue? rod failures have been observed in the older $7 \times 7$ BWR fuel assemblies. Four fuel rods have failed in PWRs from mechanical causes (mainly flow-induced) not related to the fuel design. Surmaries of Exxon Nuclear fuel performance have been presented in annual reports (Refs. 20-22).

\subsubsection{General Electric Company (GE)}

In developing its data base on BWR fuel, General Electric relies on fission product monitoring, fuel sipping, and site inspections, as well as detailed fuel inspections and postirradiation examinations. Fuel performance

\footnotetext{
(B) System 80 is a registered trademark of Combustion Engineering, Inc.
} 
TABLE 4. Summary of Combustion Engineering Fuel Irradiation and/or Discharged in 1979 (Ref.17)

\begin{tabular}{|c|c|c|c|c|c|}
\hline & $\begin{array}{r}\text { Numbe } \\
\text { Fuel Ass } \\
\text { Irradiated }\end{array}$ & $\begin{array}{l}r \text { of } \\
\text { emblies } \\
\text { nis }\end{array}$ & $\begin{array}{r}\text { Average } \\
\text { GJ/kgJ } \\
\end{array}$ & $\begin{array}{l}\text { Batch Burnup, } \\
\text { (MWd/MTU) }\end{array}$ & $\begin{array}{l}\text { Estimated No. of } \\
\text { Leaking Rods on } \\
2 / 1 / 79 \text { (Ref. }\end{array}$ \\
\hline Caivert Cliffs-1 & 289 & 72 & $337-3188(3900-36900)$ & $2220-2050(25800-20500)$ & 3 \\
\hline Calvert Cliffe-? & 281 & 64 & $172105(20025 \quad 000$ & $2321 / 260001$ & a \\
\hline 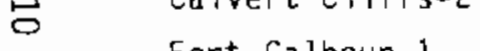 & 120 & & $7202077,0-700,23,200)$ & $2024(20,300)$ & 4 \\
\hline Fort Calhoun-1 & 139 & 0 & $752-2877(8,700-33,300)$ & 0 & 2 \\
\hline Maine Yankee & 217 & 0 & $734-2074(8,500-24,000)$ & 0 & 1 \\
\hline Millstone-2 & 289 & 72 & $346-2497(4,000-28,900)$ & $2195(25,400)$ & 1 \\
\hline Palisades & 68 & 8 & $1918 \quad(22,200)$ & 0 & 1 \\
\hline St. Lucie-1 & 285 & 0 & $372-2393(4,300-27,700)$ & $1754-1892(20,300-21,900)$ & 6 \\
\hline
\end{tabular}


results on highly precharacterized assemblies are provided in several reports listed in NUREG-0633 (Ref. 1) for years prior to 1979 . More recent results are provided in Reference 23 and in Table 5.

As with the other vendors, General Electric utilizes lead test assemblies (LTAS) as a means of either confirming design adequacy or providing early warning of negative design features. The General Electric fuel surveillance program during 1979 was focused on 21 assemblies in five reactors, as shown in Table 6. Recent information on these Monticello surveillance and Peach Bottom Unit 2. LTA programs are provided in References 24-25.

\subsubsection{Westinghouse Electric Corporation (W)}

Westinghouse provides an annual report discussing the operating experience of their fuel in domestic and foreign reactors. The detailed information on Westinghouse fuel experience up to December 31, 1979, is oresented in Reference 27. Current7y, 771,123 fuel rods are being irradiated in 31 reactors. The average burnup of all fuel irradiated to date (operating and discharged) is approximately $1728 \mathrm{GJ} / \mathrm{kg}$ (20,000 MWd/MTU), with some fuel assemblies having been discharged with a burnup of $3283-3370 \mathrm{GJ} / \mathrm{kgU}$

TABLE 5. General Electric BWR/2-5 Fuel Experience Summary $(1 / 1 / 80)$

\begin{tabular}{|c|c|c|c|c|}
\hline & \multicolumn{4}{|c|}{ Fuel Types (a) } \\
\hline & $7 \times 7$ & $7 \times 7 \mathrm{R}$ & $8 \times 8$ & $\begin{array}{l}8 \times 8 \mathrm{R} \& \\
8 \times 8 \mathrm{R}(\mathrm{PP})\end{array}$ \\
\hline Cumulative Fuel Rods Loaded & 504,161 & 285,572 & 758,015 & 268,398 \\
\hline Fuel Rods Sipped at Least Once & 504,161 & 285,572 & 563,850 & 51,522 \\
\hline $\begin{array}{l}\text { Lead Tested Batch Exposure, } \\
\text { GJ/kgU (MWd/MTU) }\end{array}$ & $\begin{array}{c}2436 \\
(28,200)\end{array}$ & $\begin{array}{c}2428 \\
(28,100)\end{array}$ & $\begin{array}{c}2220 \\
(25,700)\end{array}$ & $\begin{array}{c}1788 \\
(20,700)\end{array}$ \\
\hline Peak Power, (b) $\mathrm{kW} / \mathrm{m}(\mathrm{kW} / \mathrm{ft})$ & $\begin{array}{c}60.7 \\
(18.5)\end{array}$ & $\begin{array}{c}60.7 \\
(18.5)\end{array}$ & $\begin{array}{c}44.0 \\
(13.4)\end{array}$ & $\begin{array}{c}44.0 \\
(13.4)\end{array}$ \\
\hline Estimated Rod Failures, \% & 1.01 & 0.066 & 0.016 & 0.002 \\
\hline
\end{tabular}

(a) $\mathrm{R}=$ Retrofit fue 1 design; $P P=$ Prepressurized (3 atm)

(b) Fuel rod peak linear heat generation rate 
TABLE 6. General slectric fuel Surve $i l l$ ance Programs(a)

\begin{tabular}{|c|c|c|c|c|}
\hline Fuel Type ${ }^{(\mathrm{b})}$ & $\begin{array}{c}\text { No. of } \\
\text { Assembiies }\end{array}$ & $\begin{array}{l}\text { Program } \\
\text { Schedule } \\
\text { Start/End }\end{array}$ & $\begin{array}{l}\text { Current }{ }^{(c)} \text { Peak } \\
\text { Pellet Exposure, } \\
\text { GJ/kgU(MWd/MTU) }\end{array}$ & Utility \\
\hline $7 \times 7 \quad(1902)$ & 4 & $1974 / 198 ?$ & $3024(35,000)$ & $\begin{array}{l}\text { Commonwealth Edison } \\
\text { Quad Cities-1 }\end{array}$ \\
\hline $7 \times 7 \quad\left(\mathrm{MO}_{2}\right)$ & 1 & 1974/1982 & $2.074(24,000)$ & $\begin{array}{l}\text { Commonwealth Edison } \\
\text { Quad Cities-1 }\end{array}$ \\
\hline \multirow[t]{2}{*}{$8 \times 8$} & 1 & $1974 / 1980$ & $2765(32,000)$ & $\begin{array}{l}\text { Commonwealth Edison } \\
\text { Quad Cities-1 }\end{array}$ \\
\hline & 4 & $1974 / 1982$ & $3455(40,000)$ & $\begin{array}{l}\text { Northern States Power } \\
\text { Montice } 11 \text { ? }\end{array}$ \\
\hline \multirow[t]{2}{*}{$8 \times 8 R(I T A)$} & 4 & $1976 / 1983$ & $29] 2(33,700)$ & $\begin{array}{l}\text { Philadelphia Elecyric } \\
\text { Peach Bottom-2 }\end{array}$ \\
\hline & 2 & $1976 / 1979(d)$ & $2333(27,000)$ & $\begin{array}{l}\text { Vermont Yankee Nuclear } \\
\text { Power Corporation } \\
\text { Vermont Yankee }\end{array}$ \\
\hline $8 \times 8 R(P P)$ & 1 & $1977 / 1982$ & $2117(24,500)$ & $\begin{array}{l}\text { Philadelphia Electric } \\
\text { Peach Bottom-3 }\end{array}$ \\
\hline $\begin{array}{l}\text { 8x8(PP) } \\
\text { Barrier Clad }\end{array}$ & 4 & $1979 / 1984$ & $726(9,400)$ & $\begin{array}{l}\text { Commonwealth Edison } \\
\text { Quad Cities-1 }\end{array}$ \\
\hline
\end{tabular}

(a) Information from Reference 23 that was updated by General Electric

(b) $\mathrm{MO}_{2}=$ mixed oxide $\left(\mathrm{UO}_{2}-\mathrm{PuO}_{2}\right)$ fuel, LTA $=$ lead test assembiy, and $P P^{2}=$ Prepressurized fuel

(c) As of December 1979

(d) Discharged in September 1979

(38,000-39,000 NW/MTU). Table 7 contains a sumary of westinghouse operating experience with high burnup fuel as of June 10,1980 .

During 1979, 23 reactors reported iodine-131 activity levels in the coolant. This has led to an estimate of approximately 100 failed rods for the 23 reactors (Ref. 28). This corresponds to a defect rate of approximately $0.017 \%$. The majority of the defects are not easily visible to the unaided eye because of their small size or because they are hidden by the outer rods of 
TABLE 7. Westinghouse High Burnup Fue 1 Operating Experience as of June 10, 1980

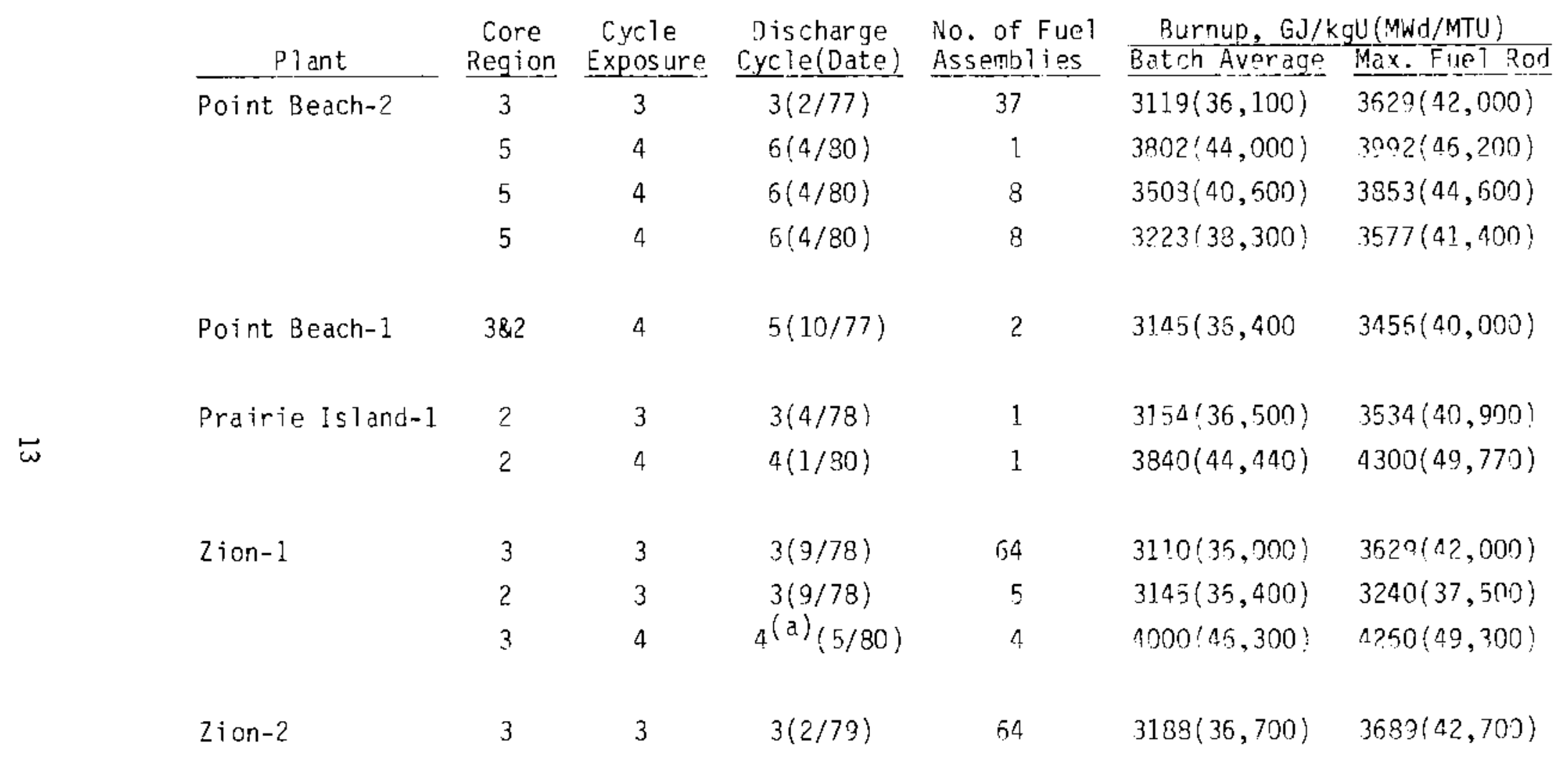

(a) Cycle 4 of Zion-2 
the fuel assembly. Approximately 6-3 cladding failures are attributable to high velocity baffle leakage, which causes failure due to fretting. (See Section 3.2 for a further discussion of this problem.)

A number of fuel assemblies are now approaching burnups in excess of 3456 $\mathrm{GJ} / \mathrm{kgU}(40,000 \mathrm{MWd} / \mathrm{MTU})$. The iodine-131 activity levels in the reactors containing these high burnup assemblies have remained constant, thus indicating that no new defects are forming. Similarly, three reactors are operating with high specific linear power ratings $(-22.3 \mathrm{kw} / \mathrm{m}$ or $\sim 6.3 \mathrm{kw} / \mathrm{ft})$ and low iodine131 activity levels. Again, this implies no measurable increase in the frequency of cladding defects.

\subsubsection{Electric Power Research Institute (EPRI)}

As stated earlier, the EPRI is extensively involved in fuel surveillance projects that are based on standard product line fuel of the type used in light-water reactors at domestic comnercial nuclear power units. These surveillance projects are a portion of EPRI's large comprehensive studv, the Light Water Reactor (LWR) Fuel Performance Program (Refs. 29-33). "The goals of this program are to develop a comprehensive fuel performance data base with verified predictive models and codes to improve fuel rod reliability and, hence, to increase plant availability" (Ref. 32). In 1973, this LWR program had nineteen active projects that ranged in scope from laboratory tests (e.g., on stresscorrosion cracking of Zircaloy) to large-scale testing of prototypic fuel assemblies. Details of these projects are fully described in planning support documents (Refs. 29 and 31); progress reports (Refs. 32 and 33) were issued in January 1978 and in February 1979. The latter report describes overa1l progress in 1978. A similar report discussing overall progress in 1979 has not been published; however, a number of reports (Refs. 10, 11, 24, and 34-45) have been issued that describe activities in 1979 on individual projects, and a brief discussion of those follows.

Hot cell examination results from the EPRI/B\&W Cooperative Project on PWR Fuel Rod Performance have been reported (Refs. 24 and 25 ). The results include data on second and third cycle cladding mechanical properties and all fuel rod destructive examination data. 
References 34-37 contain information from the EPRI/C-E Cooperative Project on PWR Fuel Rod Performance. The project involves Calvert Cliffs-Unit 1 and Arkansas Nuclear One-Unit 2 fuel. Reference 34 indicates that on six fuel rods, the fission gas release fractions ranged from 0.3 to $0.7 \%$, with no indication of burnup enhancement to $29,100:$ Md/MTU. Based on these data and earlier data (Ref. 46), it was concluded in Reference 34 "... that the current MRC $f$ ission gas release correlation is greatly over conservative when applied to prepressurized PWR fue? rod designs."

EPRI is sponsoring a project with C-E and Kraftwerk Inion (KWU), A.G., on PWR fuel rod waterside corrosion behavior. Results from this study are described in References 38 and 39. Poolside examination results from Peach Bottom Unit-? test fuel assemblies [assembly average burnup, $1166 \mathrm{GJ} / \mathrm{kgU}$ $(13,500 \mathrm{ind} / \mathrm{MTU})$; peak $10 \mathrm{cal}$ rod power, $33.8 \mathrm{kw} / \mathrm{m}(10.3 \mathrm{~kW} / \mathrm{ft})]$ associated with the EPRI/GE Cooperative Project on BWR Fuel Performance are discussed in Reference 24.

References 40 and 41 contain information on the EPRI/ENC Cooperative Project on a Power Shape Monitoring System. A newly developed technique for puncturing irradiated fuel rods and measuring the fission gas pressure and void volume of those fuel rods in a reactor's spent fuel pool is described in the latter reference. A total of 30 high-burnup Oyster Creek (BWR) fuel rods were successfully punctured and mechanicaliy resealed (the rods were reinserted in the fuel assembly, which was then returned to the spent fuel pool). Results from tinis work are presented in Reference 41.

Information on the EPRI/W Cooperative Project on PWR Fuel Performance is contained in References 42-45. That project involves irradiations in these reactors: Surry Units 1 and 2, Trojan, and Zion Units 1 and 2 . Poolside examination results from Zion-1 fuel burnup, $3110 \mathrm{GJ} / \mathrm{kgU}$ (36,000 MWd/MTU); fuel assembly average rod power, $26 \mathrm{kw} / \pi(8 \mathrm{kN} / \mathrm{ft})$ are described in Reference 44. 


\subsection{PROBLEM AREAS OBSERVED DURING 1979}

Over the years, fuel problems have been caused by a number of factors including densification, hydriding, fretting and wear, boning, and pelletcladding interaction (PCI). NRC staff reports or memoranda have been generated on each item (e.g. Reference 47 on PCI). Although resolution of several problems that were formerly of concern has been achieved (e.g., fuel densification), some old problems such as PCI remain, and some new problems have arison. The following section contains a discussion of problem areas in 1979.

\subsection{PWR BAFFLE JETTING}

On December 23, 1975, the 'Nisconsin Electric PCwer Company (WEPCO) submitted a report (Ref. 48) regarding a failed fuel assembly in Point Beach Nuclear Plant Unit 1 (Point Beach-1), a westinghouse reactor. It was subsequentiv determined (Ref. 49) that the fuel faitures were the result of wear caused by excessive fuel rod vibration. The vibration was caused by lateral jetting of coolant across the assembly face. The jetting impingement emanated from a gap in a corner joint of the core baffle. Similar fuel faitures due to "baffle jetting" have been previously observed at two foreign Westinghouse reactors, Zorita Unit 1 (Jose de Cabrera) in Spain and Mihama Unit 1 in Japan (Ref. 50).

The susceptibility of Pins to baffle jetting-type fuel damage appears to be directly related to the gap size (between two butted baffle plates that are bolted together) and the local pressure differential (flow direction in the region of the baffle and core barrel) across the cora haffle plates. It is thought that both the gap and the pressure differential must be relatively large for baffle jetting to cause damage to fuel. Nojther B\&w nor C-E plants meet both criteria. For B\&W plants, the driving pressure differential is less than $5895 \mathrm{~Pa}$ (1 psi), thus precluding significant baffle jetting. In C-E plants, the pressure differential is nigher on the core side than the bafflebarrel side, thus resulting in core coolant flow jet:ing out of the core. It is only in Westinghouse plants having downward flow in the baffle-barrel regjon that failures caused by baffle jetting have been encountered. Plants with upward flow in the baffle-barrel region permit close matching of the vertical pressure drop profile between the core region and the baffle-barrel region. 
In the Point Beach-1 case, three fuel rods on one face of a $14 \times 14 \mathrm{flde} 1$ assembly were observed to be damaged. The most severely damaged rod had a 279 m (11 in.) section of cladding missing between some spacer grids. cladding splits (with fuel pellets missing) were observed over a few centimeters (several inches) on the adjacent two rods. According to westinghouse, the cladding splits are secondary in nature, and are believed to have been caused bv hydrogen embrittlement (secondary hydriding) in conjunction with PCI, which nccurs after coolant ingress through a primary defect. Westinghouse also believes that PCI in defected rods is "aggravated by fuel-water reactions (oxidation) which result in additional fuel pellet expansion."

Since baffle jetting appears to be associated with large baffle-joint gaps (Ref. 51), Westinghouse transmitted a technical bulletin (Ref. 52) to all of its foreign and domestic two-loop plant customers. This bullet in recommended that a visual examination be conducted on the baffle-wall facing sides of fuel assemblies in identified suspect corner positions. The bulletin further recommended that the joints be "peened" if it was determined that excessively large baffle-joint gaps existed. A maximum gap size criterion of $0.076 \mathrm{~mm}$ (3 mils) was established from flow tests (these were used to determine the relationship of rod vibration to transverse coolant flux) and a knowledge of the pressure gradient and joint geometry (Ref. 51).

In 1979, fuel failure due to a tifferent type of baffle jetting was discovered. In July 1979, ten fuel assemblies in Ringhal Unit 2 were found to have failed fuel rods associated with baffle jetting from center injection joints. This was followed in November 1979 with two damaged fuel assemblies in Ko-Ri, and also in April 1980 with two assemblies in Trojan (Ref. 50). The baffle joints in all three reactors had been peened by both knife-edge and flat -1 and methods.

The two failed fuel rods in Trojan (Ref. 53) were located almost diametrically opposite each other in the core. One fuel rod, which was in a fuel assembly on the core periphery that had been operated through one cycie, had the bottom portion broken off, had an axial split that was $\sim 2.4 \mathrm{~m}(\sim 8 \mathrm{ft})$ long, and had missing pellets. The second fuel rod was in a fuel assembly that was 
in its second cycle and was currently located in an interior position in the core, but nad been located in a peripheral position in the core near an inside baffle corner during the first cycle.

In each of the described baffle jetting cases, the damage has been restricted to a few fuel rods, and coolant activities havo been rolatively low (i.e., well within technical specifications). Thus, in the NRC staff's April 17, 1980, evaluation (Ref. 51), it was deemef acceptable to permit continued power operation of potentially affected plants until fuel examinations and repairs could be performed at the next convenient refueling outage. Westinghouse has developed and submitted (Ref. 54) a correlation of iodine-131 and iodine-133 coolant activities and activity ratios with cladding fefect size and number. It is hoped that this type of correlation can be used in conjunction with operating plant coolant activity monitoring as an aid in detecting and dealing with future baffle jetting failures should any occur.

\subsection{BWR CONTROL BLADE CRACKING}

Hot cell examinations of both foreign (KRB) and domestic (Dresden Unit 1 and 0yster Creek) control rod blades have revealed cracks in some of the stainless steel tubing and a loss of boron from some absorber tubes (Ref. 55). GE has postulated that the cracking is caused by stress corrosion resulting from solidification (sintering) of the $\mathrm{B}_{4} \mathrm{C}$ particles in the tubes followed by swelling (due to helium and lithium) of the sintered $B_{4} C$ (Ref. 56). The stress in the tubes caused by the $\mathrm{B}_{4} \mathrm{C}$ swelling is believed to accelerate the integrannular corrosion that proceeds from the outside surface of the tubing.

First indications of potential problems with the absorber tubes occurred in the late 1960s (Ref. 57). In 1968, GE placed four absorber rods in fuel assemblies to be irradiated in Dresden Unit 1. Two rods, one at the middle of Cycle 1 and one at the end of Cycle 1 (EOC 1), were inspected in hot cells at the GE Vallecitos Nuclear Center; both rods were found to be sound. One of the remaining rods was examined visually in the spent fuel pool at EOC 4, proclaimed sound, then reinserted. At EOC 5 , the two remaining rods were examined 
and found to have extensive cracking and loss of $\mathrm{B}_{4} \mathrm{C}$. At that time, the rods were beyond the anticipated internal rod pressure design life as then defined by GE models.

In 1974, five tubes from a Dresden Unit 1 control blade were examined. These tubes had reached $80 \%$ of their previously defined control blade life. One of the five absorber tubes had through-wall cracks with no apparent $B_{4} C$ loss, while another had incipient cracks. General Electric stated that the cracked tube was the result of a random manufacturing flaw. In 1979, however, 45 tubes from a foreign reactor (KRB) control blade were examined in a hot cell; all tubes were found to have through-wall cracks. In addition, many of the tubes had some $B_{4} C$ missing. In 1978, seven of 13 tubes from an 0yster Creek control blade (at $80 \%$ of design life) were found to have through-wall cracks; five of the tubes had $B_{4} C$ missing.

General Electric has calculated (Ref. 56) that the end of control blade design life, as defined by neutron absorption, would be reached when the boron10 depletion averaged over the top quarter of the control blade, reaches $42 \%$. If both boron-10 depletion and boron loss are considered, a $10 \%$ reduction in worth occurs when the boron-10 depletion, averaged over the top quarter of the blade, reaches $34 \%$. That is, boron loss causes a $10 \%$ reduction in control blade worth at $80 \%$ of the previously defined end of design life (as measured by boron-10 depletion).

Based on review of available data and discussions with GE personnel, it was determined that the relationship between boron loss and boron-10 depletion was sufficiently understood "to justify BWR operation on a interim basis" provided that certain actions described in NRC's Office of Inspection and Enforcement (I\&E) Bulletin No. 79-25 (Ref. 58) are carried out. Those actions include identifying high-exposure blades, conducting shutdown margin tests, and performing destructive postirradiation examinations of highlv exposed control blades.

\subsection{PWR STAINLESS STEEL CLADDING CRACKING}

In February 1979, a preliminary notification (Ref. 59) was received regarding the detection (by sipping and visual inspection) of several leaking fuel assemblies at Haddam Neck (Connecticut Yankee). According to the Licensee Event Report (LER) issued later that month (Ref. 60), 36 of 48 
Batch 8 fuel assemblies were leaking. The best estimate, based on iodine isotope concentrations, was that at least 45 fuel rods were failed. Visual examinations (a) revealed that all of the cladding cracks were axial in nature. Crack lengths varied from less than $2.5 \mathrm{~cm}$ to a few centimeters long ("less than an inch to several inches long"), while crack widths varied from hairline to 2 ?.5-5.1 $\mathrm{mm}$ ( $0.1-0.2 \mathrm{in.}$ ).

According to Connecticut Yankee Atomic Power Companv (Ref. 51), the fue failures were all confined to one fuel batch, Batch 8 , 311 of which has now been discharged. Batch 8 is unique in that it was the only batch where the contractor, Gulf United Nuclear Fuels, utilized pellets manufactured by British Nuclear Fuels Limited (BNFL) and the fabrication services of Babcock and Wilcox.

The cause of the Batch 8 failures has still not been conclusivelv identified, though a possible failure mechanism has been identified (Ref. 61). A check on the specifications for Batches 7,8, and 9 has shown no changes, thus eliminating a design change as the cause for the failures. However, cladding contamination and welding discrepancies have been identified. In addition, BNFL has analyzed the performance of the fuel and concluded that a power ramp at the end of cycle 7 coutd have caused the failures.

To preclude further failures, operating power restrictions, based on BNFI. recommendations, have been implemented. Additional efforts include examinations of archive fuel and clading, thermal simulation tests, further fuel nodeling studies, and additional poolside examinations (Ref. 61). Also, three fuel assemblies from core 8 were shipped to the hot cell facilities at the Battel10 Columbus Laboratories for postirradiation examination (Ref. 62).

(a) The visual examinations were conducted primarily with an underwater television system that included video tape recording capability. The underwater TV examinations were supplemented with fixed periscope examinations in the reactor containment cavity. 


\subsection{BWR WATER ROD LOWER END PLUG WEAR}

On October 3, 1979, Vermont Nuclear Power Corporation reported (Ref. 53) observing wear on the lower end plug of water rods $(a)$ in two $8 \times 8 R$ demonstration fuel assemblies. Following that initial Licensee Event Report (LER), the licensee issued a second LER (Ref. 54) that orovijed a more detailed description of the probable cause of wear and corrective action to be undertaken.

The cause of the wear was attributed to vibration of the water rod by coolant cross flow within the lower tie plate flow volume. The repetitive contact of the Zircaloy lower end plug of a water rod with the stainless steel lower tie plate of the fuel assembly resulted in preferential wear of the lower end plug. The wear does not appear to occur either on fuel rods, which fit into a tapered recesses in the lower tie plates, or on $3 \times 8$ water rods that have shorter lower end pliags.

The chief concern associated with this phenomenon is possible lower end plug wear on capture rods. (b) Should the wear on a lower end plidg of a capture rod amount to a loss of approximately $38 \%$ of the material, the square lower end plug would be worn sufficiently to permit possible rotation. There could then exist a potential for loss of positive spacer grid positioning. Analysis of the data would predict (Ref. 64) that a typical water rod lower end plug would be worn to the point of having the potential for rotation (i.e., $38 \%$ of the material missing due to wear) after service in excess of 40 months.

Based on evaluation of the lower end plug wear rates and the absence of any indicated rotational movement of the water rods with worn lower end plugs, GE and the licensee have concluded that no additional corrective action is warranted at this time. In addition, a test is underway on a different lower end plug design (Ref. 65). Four $8 \times 8$ R fuel assemblies have been modified so that the water rods are replaced with special capture rods. These special capture rods have a shorter lower end plug, which should eliminate the flow-induced

(a) A water rod is similar to a fuel rod, except it is unfueled and has several holes drilled through the Zircaloy-2 cladding at the ends for water access.

(b) Water rods that position the Zircaloy spacer grids axially along the fue? assembly to maintain rod-to-rod spacing between upper and lower tie plates. 
vibration. The four assemblies were loaded into the reactor for operation during cycle 7, with the licensee planning to perform surveillance at the next refueling outage.

On December 11, 1979, the licensee and GE presented (Ref. 56) a detailed status report of their analysis of the lower end plug wear problem. As a result of the information presented, the NRC staff agreed with the conclusion that no additional action was warranted at the time.

\subsection{PWR GUIDE TUBE WEAR}

During 1973 it was observed that fretting wear was causing an unexpected degradation of control rod guide tubes (Ref. 1). This occurred when fully withdrawn control rods, in contact with guide tube walls, were set to vibrating by coolant turbulence. Because a significant loss of mechanical integrity can occur due to wear, which in turn affects safety, the NRC continues to review guide tube wear on both a generic basis and on a case-by-case basis (Refs. 57 , $58)$.

Babcock \& Wilcox has submitted an assessment on the potential for guide tube wear (Ref. 69), but did not provide either a means for predicting the wear rate, or measurements of wear on irradiated assemblies. Babcock \& dilcox licensees and applicants have therefore been required to provide confirmatory measurements on spent fuel assemblies to verify that guide tubes have not experienced through-the-wall wear (Ref. 70).

Combustion Engineering is relying mainly on chrome-plated stainless-steel sleeves for reducing control rod wear of guide tube walls. During 1979, guide tube integrity was checked at five reactors during reload outages (Refs. 71, $72,73,74,75)$; the use of sleeves continues to be an acceptable means of reducing guide tube wear (Ref. 57).

Westinghouse has submitted guide tube wear mecsurements on irradiated $14 \times 14$ fuel assemblies, a mechanistic wear model, and the impact of the wear predictions on plant design safety anatysis (Ref. 76). In addition, Westinghouse believes that their fuel designs experience less wear because their control rods are thinner, more flexible, and have relativelv more lateral support in the guide tube assembly. The NRC staff have corcluded that the westinghouse 
design is not likely to experience significant wear, however, several near-term operating license applicants have been required to submit a surveillance program (Ref. 77).

Exxon Nuclear will be supplying reload fuel for Combustion Engineering and Westinghouse plants. To reduce guide tube wear in Maine Yankee (Combustion Engineering), Exxon Nuclear fuel will incorporate a sleeved guide tube design similar to that used by Combustion Engineering (Ref. 78). Since Westinghouse plants have lower wear rates, Exxon Nuclear reload fuel will not employ design modifications to reduce guide tube wear. During 1980, Exxon Nuclear plans to survey spent fuel assemblies discharged from H. B. Robinson, Unit 2, to verify the adequacy of their guide tube design in Westinghouse plants (Ref. 79).

\subsection{CRUD AND CORROSION}

\subsubsection{Maine Yankee (PWR)}

During sipping of fuel assemblies following Cycle 4 operation of Maine Yankee, nine failed fuel assemblies were identified (Ref. 80). The sipping was conducted based on primary coolant activity levels observed during Cycle 4 operation (Ref. 81). Five assemblies, two from Batch $G$ and three from Batch $H$ were returned to the core after the failed rods in each were identified and replaced. It is believed (Ref. 81) that a total of 15 to 25 fuel rods failed, of which 11 were positively identified.

The faflures were associated with excessive "crud" deposits, which are believed to have affected fuel rod-to-coolant heat transfer and peak cladding temperature. Although the cause of the excessive amount of crud has not been determined, the core pressure drop is being closely monitored, core power is periodically reduced, and hydrogen peroxide injections are made in an attempt to flush out the crud (which is reportedly a non-adherent type) (Ref. 82).

Combustion Engineering has prepared two reports (Ref. 83 and 84 ) based on inspections made of the failed fuel.

\subsubsection{Vermont Yankee (BWR)}

In late March 1979, Vermont Yankee underwent an interim refueling outage due to a trend of increasing off gas (Ref. 85). A total of 31 leaking $8 \times 8$ 
fuel bundles (including six bundles identified in September 1979 at EOC 5) were identified by sipping (Ref. 65). A total of 75 rods were failed (71 containing gadolinia and four containing $\left.\mathrm{UO}_{2}\right)$. All the damaged fuel was removed, alona with all the gadolinia rods (because of the apparent en'anced failure susceptibility of such poison rods).

Destructive and nondestructive examinations nerformed at the GE Vallocitos Nuclear Center, together with examination of fabrication records, indicated that neither contamination, PCI, hydriding, overheating (thermal/hydrautic event), nor nuclear anomalies were likely causes of the failures (Refs. 55 and 86). The failures appeared to be caused by external corrosion associated with a variably high metal ion concentration in the reactor primary coolant. Chemical analysis of crud deposits on the failed support this thesis. Genera? Electric is advising their customers to monitor ard control the reactor water conductivity, and expects no recurrence of the prcblem (Ref. 86).

\subsection{WESTINGHOUSE GRID STRAP DAMAGE}

In the process of reloading Salem Unit 1 for Cycle 2 operation, it was noted by the 1 icensee on May 5,1979 , that some of the fuel assemblies had suffered grid strap damage (Ref. 87). Subsequent to that discovery, all the fuel assemblies were removed from the core for examination. The degree of damage to the grid straps was classified into three cateqories: 1) small pieces missing (15 assemblies), 2) grid material ripped and laid over (5 assemblies), and 3) larger sections missing and fuel rods exposed (11 assemblies). A total of 31 of the Westinghouse $17 \times 17$ assemblies had suffered some grid damage (Ref. 88).

At a meeting held with the licensee and Westinghouse on May 25, 1979 (Ref. 39), it was learned that Category 1 and Category ? types of damage were deemed acceptable for in-reactor use and fuel assemblies in those categories would be reloaded for Cycle 2. As a precaution, fuel assemblies with Category 3 damage were not to be reloaded. Although Salem Unit 2 is the first reported instance of large-scale grid damage, Westinghouse acknowledged (Ref. 89) that similar damage has heen observed in $14 \times 14,15 \times 15$, and $17 \times 17$ fuel assemblies in other plants. 
Westinghouse has recommended additional fuel assemblv handing precautions to minimize the potential for corner-to-corner interactions between spacer grids on one fuel assembly with those on another fuel assembly the assumed cause of the problem) (Ref. 39). In addition, an I\&E circular requiring further action by all licensees reloading Westinghouse $17 \times 17$ fuel assemblies has been issued for comment (Ref. 90). The required actions include (a) visual inspection of grid straps on discharged fuel assemblies and (b) review of the fuel handling precautions recommended by Westinghouse at the May 25, 1979, meeting. As stated in the circular, if damage of this type were to recur, consideration would be given to requiring modification of the manipulator crane load cell to automatically interrupt fuel assembly motion at a point where forces exceeded acceptable limits.

\subsection{WESTINGHOUSE CONTROL SPIDER RODLET FAILURES}

A Westinghouse rod control cluster assembly (RCCA) consists of individual neutron absorbing rodlets fastened at the top end to a common spider-shaped body. On May 31, 1979, during the refueling outage for Cycle 2 at Salem Unit 1 , some rod control cluster assemblies were found with missing individual rodlets (Ref. 91). The missing rodlets had broken away from the spiders and fallen into their respective fuel assembiy guide tubes. Six RCCAs with a total of eight detached rodlets (four RCCAs with one broken rodlet each and two RCCAs with two broken rodlets each) were found (Ref. 92). Examinations of the failed RCCAs revealed that the failures occurred in the threaded area of the fingers (female fittings) into which the rodlets (male fittings) are threaded, torqued, and pinned. All of the dropped rodlets were traced to two receiving lots of fingers from a single manufacturing subcontractor.

Al1 of the fuel assemblies containing dropped rodlets and all 25 of the RCCAs with fingers from the two suspect receiving lots were removed from the reactor. An NRC safety evaluation (Ref. 93) concluded that the failures resulted from a manufacturing problem and that a generic design error did not exist. Because of limited experience with cores containing $17 \times 17$ type fuel assemblies, an I\&E circular was drafted (Ref. 90) that would have advised licensees of Westinghouse plants using $17 \times 17$ fuel assemblies to (a) develop a surveillance plan to detect broken rodlets during refueling to assure that 
RCCAs with missing rodlets would not be reused, and (b) examine core flux maps taken during startup tests and during operation for the presence of flux depressions that might reveal the presence of dropped rodlets. However, because of the following reasons, the plan to issue an I\&E circular was dropped (Ref. 94):

(a) No safety probiems are expected to result from a few $(<10)$ dropped rodiets (Ref. 95),

(b) If enough rodlets (2-5) dropped to significantly affect the operating characteristics of the core, some remedial action (involving control rod insertion or boron addition) would be necessary by the operator to maintain the core within Technical Specification linits,

(c) Westinghouse provided licensees with guidance nn detection of dropped rodlets (Ref. 95 ), and

(d) Surveillance was already underway by licensees to detect dropped rodlets.

Current plans are to reevaluate the need for generic corresoondence if inspection results indicate additional failures or 1 ack of response to Westinghouse correspondence.

\subsection{EXTENSIVE CORE DAMAGE - THREE MILE ISLAND UNIT? (PWR)}

The accident at Three Mile Island Unit 2 (TMI-2) on March 28, 1979, caused extensive damage to the core. This accident has prompted a large number of investigations into the cause of the accident, the behavior of the reactor during the accident, and related subjects. It is impractical to reference here all the material that has been produced relative to TMI-?. Therefore, four major sources of information will be identified. First, President Carter commissioned John Kemeny to head up an investigation of the accident (Ref. 97). Second, Mitche 11 Rogovin was hired by the NRC to investigate the accident relative to NRC actions (Ref. 98). Third, an NRC report evaluating the long-term post-accident cooling of TMI-2 has been prepared (Ref. 99). And fourth, the 
Nuclear Safety Analysis Center of the Electric Power Research Institute Center has issued a bibliography of TMI-2 related material in their files as of December 31, 1979 (Ref. 100). 


\subsection{FUEL DES IGN CHANGES}

As a result of the PCI problem ${ }^{(a)}$ and the desire to improve uranium utilization (e.g., by having fuel go to higher burnup, by reducing neutron absorption, or by reducing neutron leakage), several programs (Refs. 9, 27, 33, and 101-104) are investigating the commercial acceptability of improved fuel concepts. Barrier and liner fuel designs are involved in the Commonwealth Edison/GE program; as noted in Table 6, four fuel assemblies were placed in Quad Cities Unit 1 in 1979. In the Consumers Power Company/ENC/PNL orogram (Ref. 103), an annular-coated-pressurized design and a sphere-pac design are being evaluated by means of steady-state and ramping irradiations and their performance is being compared with a reference fuel design. Four fuel assemblies containing demonstration fuel rods were inserted in Big Rock Point during the spring of 1979. As shown in Table 2, irradiation of other fuel assemblies with design changes (e.g., use of an optimized design, low absorption spacer grids, or axially blanketed fuel columns) has comrienced.

(a) PCI is the principal concern regarding fuel failure at higher burnup with present LWR fuel (Ref. 101). The PCI phenomenon is generic to reactors using Zircaloy-clad U02 fuel (Ref. 105). 


\subsection{REFERENCES}

1. M. D. Houston, Fuel Performance Annual Report (Period through December 1978). NUREG-0633, U.S. NucTear Regulatory Commission, December 1979. ${ }^{\star}$

2. Regulatory Guide 1.16 through Revision 5, "Reporting of Operating Information - Appendix A Technical Specifications," 1971 to 1979.

3. Office of Management Information and Control, Nuclear Power Plant Dperating Experience 1974-1975. NUREG-0227, U.S. Nuc Tear Regulatory Commis-

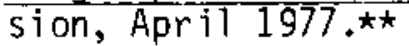

4. Office of Management Information and Control, Nuclear Power Plant Operating Experience 1976, NUREG-0366, U.S. Nuclear Regulatory Commission, December $1977 . \star \star$

5. M. R. Becke, Nuclear Power Plant Operating Experience_1977, NUREG-0483, February 1979,*

6. U.S. Nuclear Regulatory Commission Standard Review Plan, Rev. 1. NUREG$75 / 087$ (presentTy NUREG-0800).$^{\star \star}$

7. V. Stello (NRC), Memorandum to R. C. DeYoung, "Supplemental Surveillance of $17 \times 17$ Fuel Assemblies," November 14, 1974.

8. Reference deleted

9 J. H. Taylor (B\&W), Letter to M. Tokar (NRC), July 3, 1980.

10. G. M. Bain and T. P. Papazoglou, Hot Cell Examination of Creep Collapse and Irradiation Growth Specimens, End of Cycle 2. LRC 4733-7, Babcock \& Wilcox Company, Lynchburg Research Center, August 1979. (Key Phase Report No. 4, EPRI Research Project RP711-1, EPRI/B\&W Cooperative Project on PWR Fue? Rod Performance).

11. W. A. Pavinich and T. P. Papazoglou, Hot Cell Examination of Creep Collapse and Irradiation Growth Specimens, End of Cycle 3. LRC 4733-8, Babcock \& Wi icox Company, Lynchburg Research Center, March 1980. (Key Phase Report No. 5, EPRI Research Project RP-711-1).

12. Post-Irradiation Examination of Oconee 1 Fuel, Cycle 1 Nondestructive Test Phase. BAW-1519, Babcock \& Wilcox, Lynchburg, Virginia, June 1979.

13. Post-Irradiation Examination of Oconee I Fuel, Cycle 1 Destructive Test Phase. BAW-1535, Babcock \& WiTcox, Lynchburg, Virginia, June 1979.

14. T. D. Pyecha et al., Nondestructive Examination of Oconee 1 Fue 1 Assemblies After Three Cycles of Irradiation. C00-4711-20 (BAW-1553), Babcock \& Wilcox, Lynchburg, Virginia, September 1979. 
15. Oconee 1, Cycle 5 Design Report. BAw-1520, Babcock \& Wilcnx, L-unchbura, Virginia, May 1979 .

16. T. A. Coleman et al., Qualification of the S\&W Mark B Fuel Assembly for High Burnup - First Semi-Annual Progress Report, July-Decemi 1978 . BA

17. A. E. Scherer (Combustion Engineering), Letter to R. O. Mever (NRC), "197a Fue 7 Performance Data", JuTy 1, 1280.

18. H. G. Andrews, K. R. Freeburn, and W. D. Worlsen, "The Performance of Combustion Engineering Fue T in Operating PWR's." Proceedings of the MIS Topical Meeting on Light Water Reactor Fuel Performance, Portiand, ORR, Apri1 29-May 3, 1979 (pp. 11-19).

19. Reference deleted

20. P. 0. Farnsworth, Fuel Performance Report NC.?. XN-75-13 (Proprietary), Exxon Nuclear Co., Richland, WA, February $\overline{19} \overline{7}$. This document is not publicly available because it contains proprietary information.

21. W. C. Ga1laugher, Sumary of ENC Fuel Performance. XN-75-50 (Proprietary), Exxon Nuclear Co., Richland, WA, November 3, Ja7s. This document. is not publicly available because it contains proprietary information.

22. K. N. Woods, Sumary of ENC Fuel Performance Through necember 1977. XN. NF-78-2 (Proprietary), Exxon Vuclear Co., Richland, WA, January 1978. This document is not publicly available bocause it contains proprietary information.

23. W. E. Baily, J. 5. Armijo, J. Jacobson, and R. A. Proebstle, "BdR Fuel Performance," Proceedings of the ANS Topical Meeting on Light Water Reactor Fue 1 Performance, Port and, OR, Apri1 $29-$ May $3,1079$. (pp. 1-10)

24. D. 0. Sheppard, Boiling Water Reactor Fuel Rod Performance Evaluation Program, Task $C$ : Second Cyc le Interim Site Examination of the Lead Tost Assemb $1 y$ Fue $\bar{T}$ and Channels at Peach Bottom 2 . NEDC-24609. Genera Electric Company, February 1979. (EPRI Research Project RP $510-1$, the EPRI/General Electric Cooperative Project on BWR Fue? Performance, is part of the Fue] Bundle Studies Subprogram within the EPRI l-ight water Reactor Fuel Performance Program). This document is not publiclv available because it has not been reviewed to determine whether it contains patentable subject matter, nor has the accuracy of its information or conclusions been evaluated. 
25. M. H. Skarshaug, $8 \times 3$ Fuel Surveillance Program Monticel10 Site - End of Cycle 5. Third Post-Irradiation Inspection. NEDE-25195 (Proprietary), October 1979 . This document is not publicly available because it contains proprietary information.

26. M. H. Skarshaug, $8 \times 8$ Fue 1 Surveillance Program Monticello Site-End of Cycle 6. Fourth Post-Irradiation Inspection. NEDE-25245 TProprietary, December 1379. This Jocument is not publicly available becalse it contains proprietary information.

27. J. Skaritka and 3. A. Iorii, Operational Experience with Westinghouse Cores (Up to December 31, 1979). WCAP-3183, Rev. 9 , Westinghouse Electric Corp., Pittsburgh, PA, April 1980.

23. John Skaritka (Westinghouse), Letter to M. Tokar (NRC), June 10, 1980.

29. J. T. A. Roberts and F. E. Gelhaus, Planning Support Document For the EPRI Light Water Reactor Fuel Rod Performance Program. EPRI SR-25, Electric Power Research Institute, PaloA A to, CA, December, 1975.

30. EPRI Cooperative Program Presentations, Electric Power Research Institute Sponsored Meeting, Dallas, Texas, April 1977.

31. J. T. A. Roberts et al., Planning Support Document for the EPRI Light Water Reactor Fue? Program. EPRI NP-370-SR, Electric Power Institute, Palo Äto, CA, January 1977.

32. 3. T. A. Roberts et a\}., Planning Support Document for the EPRI Light Water Reactor Fuel Performance Program, Supplement No. 1: Progress in 1977. EPRI NP-737-SR, Electric Power Research Institute, PaTo ATto, CA, January 1978.

33. J. T. A. Roberts et al., LWR Fuel Performance Program: Progress in 1978. EPRI NP-1024-SR, Electric Power Research Institute, February 1979.

34. S. R. Pat 1 , Fuel Performance Evaluation in $14 \times 14$ Assemblies: Gas Release and Microstructural Evaluation of One - and Two - Cycle Fuel Rods from CaTvert CliffS-I. NPSD-75, Combustion Engineering, Inc., March 1979. (Task A, EPRI Research Project RP 586-1, EPRI/Combustion Engineering Cooperative Project on PWR Fuel Performance, which is part of the Fuel Bundle Studies Subprogram within the EPRI LWR Fuel Performance Program).

35. E. J. Ruzauskas, J. G. Schneider, and P. A. Van Saun, Fuel Performance Evaluation Program: Examination of Calvert Cliffs I Test Fuel Assembly After Cycle 3. Combustion Engineering, Inc., September 1979. (Task A, EPRI Research Project RP586-1). 
36. D. E. Bessette, D. S. Kneppel, and B. Riley, Fabrication and Characterization of Arkansas Nuclear One - Unit II $15 \times 16$ Fuel Assemblies. Combustion Engineering, Inc., October 1373. TTask B, EPRI Research Project RP 586-1).

37. D. S. Kneppe1, Fue 1 Performance Evaluation Program: Ex-Reactor Creep Behavior of Zircaloy-4 Tubing Used in Arkansas Nuclear One-Unit II Fue Assemblies. Combustion Engineering, Inc., October 1979. TTask B, EPRI Research Project RP 586-1).

38. Review of PWR Fuel Rod Haterside Corrosion 3ehavior. NPSD-79, Combustion Engineering, Inc., June 1979. TTask A, EPRI Résearch Project RP1250-01, EPRI-sponsored joint program with Combustion Engineering (C-E), Inc., and Kraftwerk Union Aktiengesellschaft (KWJ) to investigate PWR waterside corrosion of Zircaloy-clad fuel rods).

39. F. Garzarolii, D. Jorde, and R. Manzel (Kraftwerk Union, A.G.); G.W. Parry and P, G. Smerd (Combustion Engineering, Inc.), Review of PWR Fue 1 Rod Waterside Corrosion Behavior. EPRI NP-1472, Interim Report, August 1980. (EPRI Research Project 1250-]).

40. J. D. Kahn, Pre-Irradiation Data for Specially Characterized Oyster Creek Cycle 8 Fuel Assemblies. XN-NF-78-14 Revision 1, Exxon Nuclear Company, Inc., February 1979. (EPRI Researich Project RP895-1-4, EPRI/Exxon Niclear cooperative project on a power shape monitoring system to evaluate the effects of core power maneuvers on fuel rod reliability).

41. Leo F. Van Swam, Site-Based Fission Gas Release Measurements at the Dyster Creek Reactor. XN-NF-79-60, Exxon Nuciear Company, January 1980. (EPRI Research Project RP895-1-4).

42. G. R. Schmidt et a1., Inter im Report Surry Unit 2, EOC-3 Onsite Fuel Examination of $17 \times 17$ Demonstration Assemb iss after Two Cycles of Exposure. WCAP-9238, Westinghouse Electric Coro., January 1979. This document is not publicly available because 't contains prepublication information. Formal publication is to be made under EPRI contract RP611-1 (EPRI/Westinghouso Cooperative Project on PIR Fuel Performance, which is part of the Fue? Bundle Studies Subprogram within the EPRI Light Water Reactor Fuel Performance Program).

43. E. J. Tarby et al., Interim Report Zion Unit 1 Cycle 2 Fuel Performance. WCAP-9255, Westinghouse ETectric Corp., January 1979. This document is not publicly available because it contains prepublication information. Formal publication is to be made under EPRI Contract RP611-1.

44. H. H. Crain et al., Interim Report Zion Unit 1 Cycle 3 Fuel Performance. WCAP-9533, Westinghouse Electric Corporatior, September 1979. This document is not publicly available because it contains prepublication information. Formal publication is to be made urder EPRI Contract RP511-1. 
45. G. R. Schmidt and J. B. Melehan, Fabrication and Characterization of Trojan Unit 1, Region 1, 2 and 3 Fuel Assemblies. WCAP-9333 (Proprietary), Westinghouse Electric Corporation, October 1978. (EPRI Research Project RP 611-1.). This document is not publicly available because it contains proprietary information.

46. J. T. A. Roberts et a1., LWR Fuel Performance Program: Progress in 1978. EPRI NP-1024-SR, Electric Power Research Institute, february 1979. (o. 3-26, EPRI/B\&iW Research Project RP711).

47. M. Tokar (NRC), Memorandum to M. W. Libarkin (Assistant Executive Director for Project Review, ACRS), "Report to ACRS Concerning NRR Efforts on Pellet/Cladding Interaction," November 14, 1979.

48. S. Burstein (Wisconsin Electric Power Company), Letter to B. Rusche (NRC), December 23, 1975.

49. S. Burstein (Wisconsin Electric Power Company, Letter to B. Rusche (NRC), December 30, 1975.

50. C. P. Yundt (Portland General Electric Co.), Letter to R. H. Engelken (NRC), August 18, 1980.

51. Paul S. Check (NRC), Memorandum to Lester S. Rubenstein (NRC), "Westinghouse Bafflo-Jetting," April 17, 1980.

52. "Examination of Fuel Assemblies at Corner Peripheral Core Baffle Locations," Westinghouse Nuclear Service Division Technical Bulletin NSD-TB$76-1$, January 19, 1976.

53. Preliminary Unusual Dccurrence Report, PNO-V:80-32, Apri1 25, 1980.

54. C. Eicheldinger (Westinghouse), Attachment to Letter (NS-CE-1541) to D. G. Eisenhut (NRC), September 9, 1977 .

55. Darrell G. Eisenhut (NRC), Memorandum to Division Directors, Office of Nuclear Reactor Regulation, "Information Memorandum No. 18--New? Failure Mode for BWR Control Blades," October 22, 1979.

56. K. W. Brayman and K. W. Cook, Evaluation of Control Blade Lifetime with Potential Loss of B4C. NEDO-24226, General ETectric Co., December 1979.

57. R. L. Gridley (GE), Letter to Paul S. Check (NRC), "Response to NRC Additional Question on Control Blade Life (B4C Loss)," June 29, 1979.

58. Norman C. Moseley (NRC), Memorandum for B. H. Grier et al., IE Bulletin No. 79-26, "Boron Loss from BUR Control Biades," November 19, 1979.

59. Preliminary Notification of Event or Unusual Occurrence, PN0-79-27, "Abnormal Degradation of Fuel Cladding", February 16, 1979. 
60. License Event Report 79-001/1T-0, February 28, 1979.

61. Richard H. Graves (Connecticut Yankee Atomic Power Company), Letter to Boyce Grier (NRC), July 31, 1970.

62. Richard H. Graves (Connecticut Yankee Atomic Power Company), Letter to Boyce Grier (NRC), JuTy $16,1980$.

63. Licensee Event Report 79-025/01P, October 3, 1979.

64. Licensee Event Report 79-025/01T-0, Octoder 17, 1979.

65. J. S. Charnley (GE), Letter to Frank] in D. Coffman (NRC) with "Copy of Presentation S1ides - December 11, 1979, Meeting on Vermont Yankee Fue 1," December $11,1979$.

66. Vernon L. Rooney (NRC), "Meeting Held on December 11, 1979, to Discuss Vermont Yankee Fuel History and Water Rod Wear, "January 16, 1380.

67. D. A. Powers (NRC), Memorandum to R.O. Mever (NRC) "Guide Tube Wear Input for the Annual Report", November 17, 1980.

68. R. Riggs, Control Rod Guide Tube Wear in Operating Reactors: Operating Experience Report. NUREG-0641, IJ.S. NucTear Regulatory Commission, Aprî 1980**

69. 3. H. Taylor (Babcock \& Wi]cox), Letter to 3. K. Grimes (NRC), January 12, 1979.

70. L. S. Rubenste in (NRC), Letter to S. H. Howell (Consumers Power Company), "Request for Additional Information on Fuel Assembly Guide Tube Wear for Midland Plant, Units 1 and 2". Docket Nos. 50-329/330, November 15, 1979.

71. T. E. Short (Dmaha Pub7ic Power District), Letter to Director of I\&E, NRC, Docket No. 50-285, March 1, 1979.

72. W. G. Council (Northeast Utilities), Letter to R. Reid (NRS), "Sleeved CEA Guide Tube Inspection", Docket No. 50-336, May 23, 1979.

73. R. E. Uhrig (Florida Power and Light Company), Letter to R. W. Reid (NRC)," CEA Guide Tube Inspection/Evaluation", Docket No. 50-335, May 23, 1979.

74. W. J. Lippold (Baltimore Gas and Electric Company), Letter to E. Conner (NRC), Docket No. 50-317, May 24, 1979.

75. R. C. L. 0lson (Baltimore Gas and Electric Company), letter to R. W. Reid (NRC), "CEA Guide Tube Inspection Program", Docket No. 50-318, November 12, 1979. 
76. T. M. Anderson (Westinghouse), Letter to D, G. Eisenhut (NRC), NS-TMA2012, June 27, 1379.

77. L. S. Rubenste in (NRC), Letter to H. G. Parris (Tennessee Valley Authority)," Degradation of Guide Thimble Tube Walls, Docket Nos. 50$327 / 328$, December $14,1979$.

78. R. H. Groce (Maine Yankee Atomic Power Company), Letter to R. W. Reid (NRC), "Questions Pertaining to Cycle 5 Reload Fuel", Docket No. 50-309, November 6, 1979.

79. G. F. Owsley (Exxon Nuclear), Letter to T. A. Ippolito (NRC), December 5, 1979.

80. Licensee Event Report 30-004/01T-1, February 14, 1980.

81. R. H. Graves (Maine Yankee Atomic Power Company), Letter to Robert $N$. Reid (NRC), March 10, 1980.

82. Reference deleted

33. End-of-Cycle 4 Fuel and CEA Eddy Current Inspection Report; 1980 Maine Yankee Refueling Outage. CEN-129(M)-P (Proprietary), Combustion Engineering, Inc., March 24, 1980. This document is not nublicly available because it contains proprietary information.

84. Maine Yankee End-of-Cycle 4 Summary of Fue I Inspection Results. C.EN-131 (M) -P (Proprietary), Combustion Engineering, Inc., March 1980. This document is not publicly available because it contains proprietary information.

35. General Electric Projects Division Memorandum, "Vermont Yankee Fuel Failure Status," April 6, 1979.

85. R. E. Engel (GE), Letter to M. Tokar (NRC), "Subject: Corrosion Product Control," October 3, 1980.

87. Licensee Event Report 79-044/03L-1, July 30, 1979.

88. Darrell G. Eisenhut (NRC), Memorandum for Division Directors, NRR, "Information Memoranduin No. 19--Westinghouse 17 x 17 Grid Damage," october 25, 1979.

89. Gary G. Zeck (NRC), "Summary of Meeting Held on May 25, 1979, to Discuss Damage Dbserved to Fuel Grid Assemblies During the Salem Unit No. 1 Refueling Outage," May 30, 1979.

90. Brian K. Grimes (NRC), Memorandum to Norman C. Mosely, "Proposed I\&E Circulars on Westinghouse 17 x 17 Rodlet Drops and Grid Strap Damage," October 25, 1979. 
91. Licensee Event Report 79-047/03L-1, July 30, 1979.

92. Darrell G. Eisenhut (NRC), Memorandum for Division Directors NRR, "Information Memorandum No. 18--Westinghouse 17 × 17 Rod1et Drops," October 25, 1979 .

93. P. S. Check (NRC), Memorandum to A. Schwencer, "Salem Unit 1, Cycle 2 Re?oad Safety Evau?ation," September 6, 1979.

94. Edward L. Jordan (NRC), Memorandum to B. K. Grimes, "Proposed Circular on Westinghouse $17 \times 17$ Rodlets," Aprit 9, 1980.

95. M. D. Houston (NRC), Memorandum to K. Kniel, "Westinghouse Control Spider Failures," November 13, 1979.

96. T.M. Anderson (Westinghouse), Attachment to Letter to Paui Check (NRC), September 4, 1979.

97. John C. Kemeny, Chairman, U.S. President's Commission on the Accident at Three Mile Island; The Need for Change: Legacy of TMI. Pergamon Press, New York, 1979. 201p.

98. Mitchell Rogovin (Director) and George T. Frampton, Ir. (Deputy Director), U.S. Nuclear Regulatory Commission Special Inquiry Group. Three Mile Island: A Report to the Commissioners and to the Public. NUREG/CR1250, Vol. I and Vol. II (Parts 1-3), 1979.*

99. Evaluation of Long-Term Post-Accident Core Sooling of Three Mile Is land Unit 2. NUREG-0557, Apri1 1979. ${ }^{\star}$

100. Indexed Bibliography of TMI-2 Documents in NSAC Working File; Accumulated Through December 31 , 1979. NSAC-Bib. 4, Nuilear Safety Analys is Center, ETectric Power Research Institute, January 1980.

101. Peter M. Lang, "Future Trends in LWR Fuel to Improve Uranium Utilization", Trans. Am. Nucl. Soc.30:274-275, November 1978 .

102. C. E. Crouthamel (compiler), Fuel Performance Improvement Program. Quarter 1 y/Annual Progress Report, 0ctober 1979-September 1979. C00-406613, 0ctober 1979 .

103. C. E. Crouthamel and M. D. Freshley, Fuel Performance Improvement Program, Semiannual Progress Report, October 1979-March 1980. DOETET/3421516 , Aprii 1980.

104. "DOE, TVA, and GE Initiate Joint Study to Improve Uranium Fuel Efficiencies", Nuclearfue], po. 16-17, February 5, 1979. (a McGraw-Hill publication).

105. Adrian Roberts and Howard Ocken, "Improving Nuclear Fuel Reliability," EPRI Journal, pp. 75-79, October 1978.

FAvailable for purchase from the NRC/GPO Sales Program, U.S. Nuclear Regulatory Commission, Washington, $D C$ 20555, and the National Technical Information

* Service Springfield, VA 22161 for National Technical Information Service. 
NUREG/CR-1818

PNL -3583

$\mathrm{R}-3$

\section{DISTRIBUTION}

No. of

Copies

OFFSITE

A. A. Churm

DOE Patent Division

9300 5. Cass Avenue

Argonne, IL 60439

400 Nuclear Regulatory Commission

Division of Technical Information and Document Control

7920 Norfolk Avenue

Bethesda, MD 20014

2 DOE Technical Information Center

4 W. V. Johnston

Chief, Core Performance Branch

Division of Systems Integration

Office of Nuclear Reactor

Regulation

U.S. Nuclear Regulatory

Comm ission

Washington, DC 20555

R. 0. Meyer

Core Performance Branch

Division of Systems Integration

Office of Nuclear Reactor

Regulation

U.S. Nuclear Regulatory

Comm ission

Washington, DC 20555

M. Tokar

Core Performance Branch

Division of Systems Integration

Office of Nuclear Reactor

Regulation

U.S. Nuclear Regulatory

Comm ission

Washington, DC 20555
No. of

Copies

ONSITE

46 Pacific Northwest Laboratory

W. J. Bailey (12)

J. 0. Barner

S. 0. Bates

W. D. Bennett

C. E. Beyer

M. E. Cunningham

A. G. Dunbar

M. D. Freshley

R. L. Goodman

R. J. Guenther

C. R. Hann

K. A. Hsieh

D. D. Lanning

R. R. Lewis

R. K. Marshall

C. L. Mohr

C. Nealley

F. E. Panisko

L. J. Parchen

W. N. Rausch

G. E. Russcher

R. E. Schreiber

R. A. Scoggin

M. S. Smith

N. J. Wildung

R. E. Williford

C. L. Wilson

Technical Information (5)

Publishing Coordination Fe (2) 



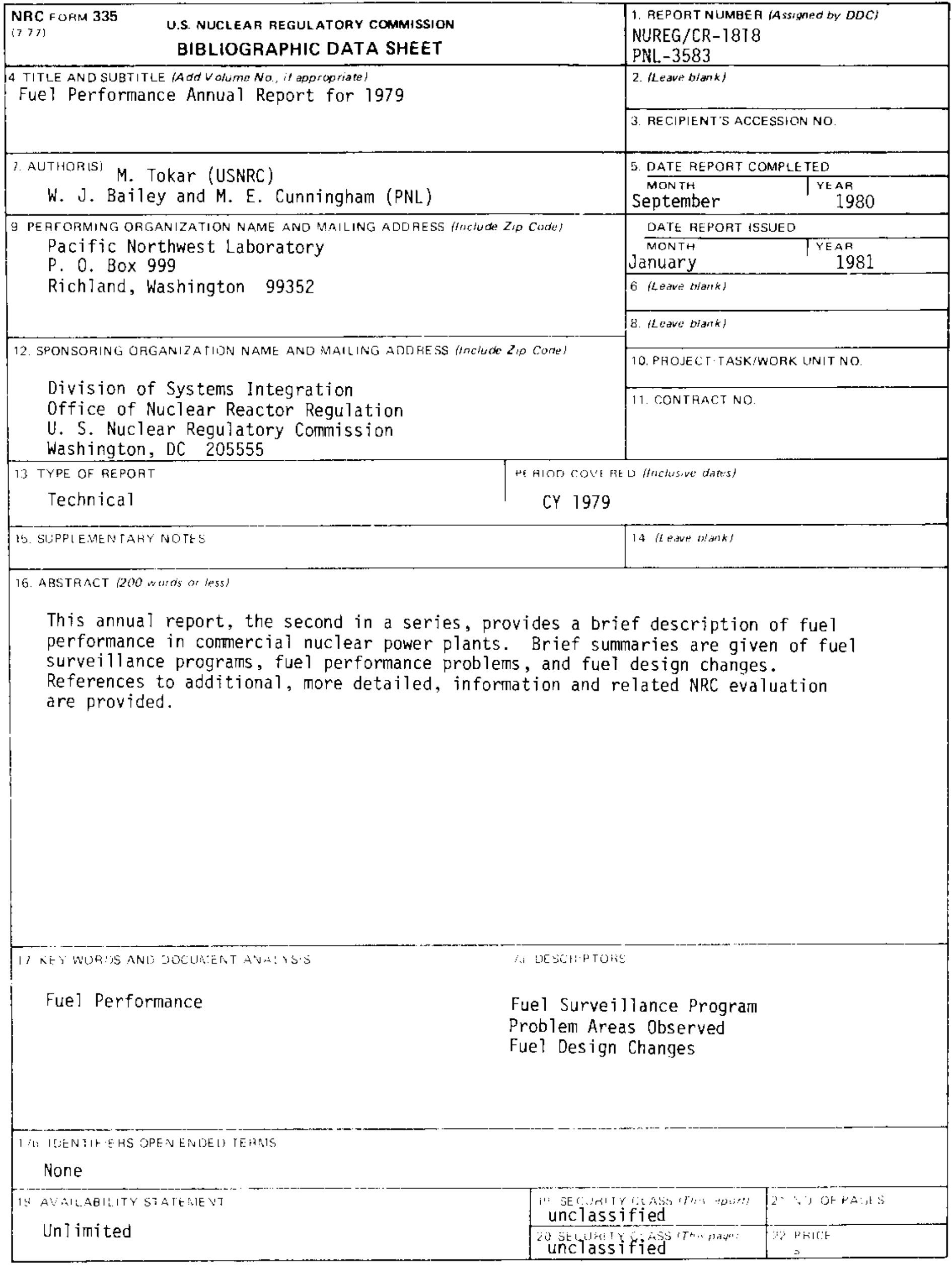


